Prepared in cooperation with the Indiana Office of Community and Rural Affairs

\title{
Flood-Inundation Maps for the East Fork White River at Shoals, Indiana
}

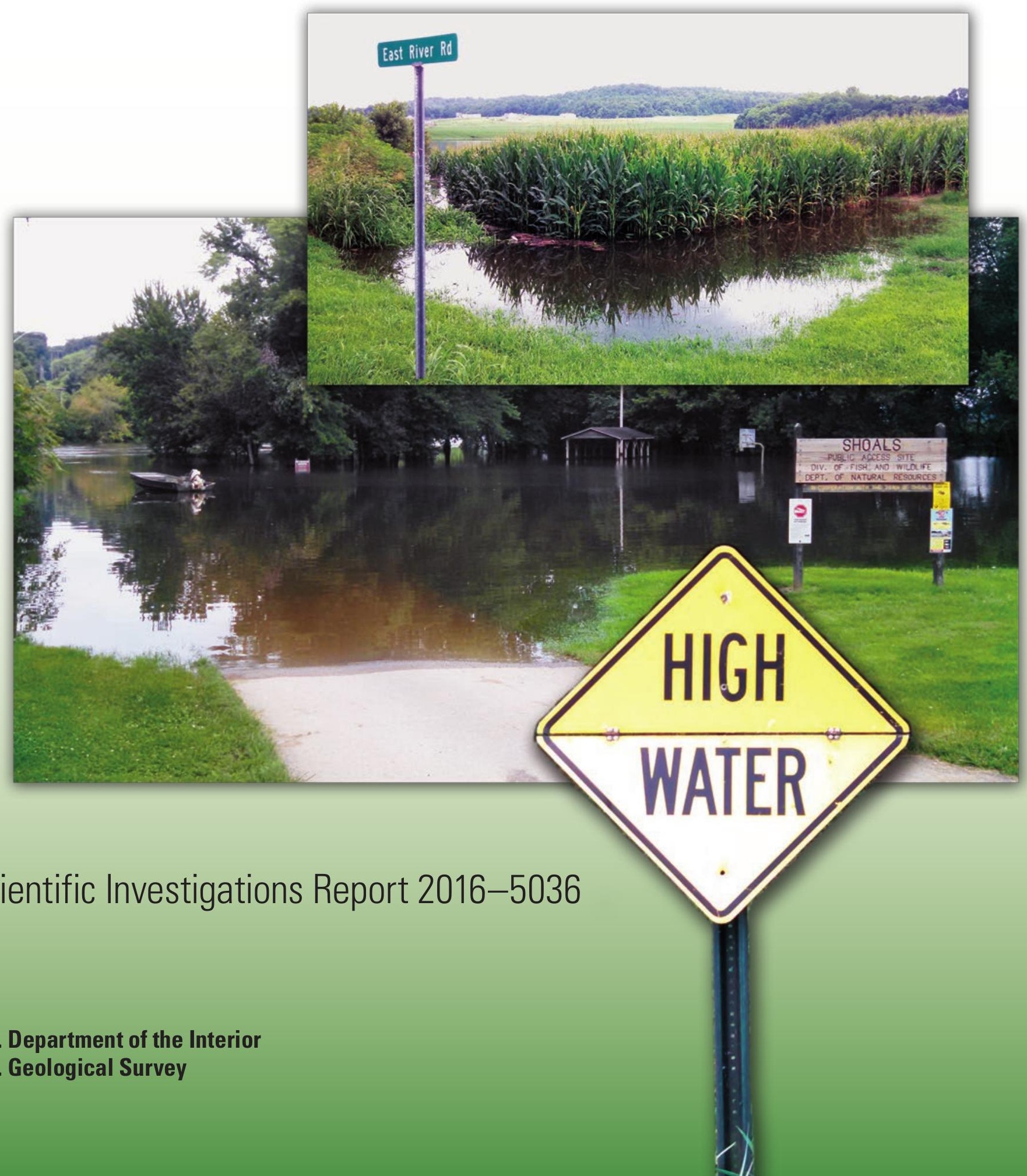

U.S. Department of the Interior

U.S. Geological Survey 
Front cover. Photocomposite showing flooding at the East Fork White River at Shoals, Indiana, July 20, 2015. Photos by Justin A. Boldt, U.S. Geological Survey. (Top: flooded corn field at the northeast corner of County Road 91 and East River Road; bottom: flooded boat ramp and recreational area at 8 th Street.)

Back cover. Overlook view of the East Fork White River (looking upstream) from the bluffs along U.S. Highway 50/150, north of Shoals, Indiana, July 20, 2015. Photo by Justin A. Boldt, U.S. Geological Survey. 


\section{Flood-Inundation Maps for the East Fork White River at Shoals, Indiana}

By Justin A. Boldt

Prepared in cooperation with the

Indiana Office of Community and Rural Affairs

Scientific Investigations Report 2016-5036 


\title{
U.S. Department of the Interior SALLY JEWELL, Secretary
}

\section{U.S. Geological Survey Suzette M. Kimball, Director}

\author{
U.S. Geological Survey, Reston, Virginia: 2016
}

For more information on the USGS - the Federal source for science about the Earth, its natural and living resources, natural hazards, and the environment—visit http://www.usgs.gov or call 1-888-ASK-USGS.

For an overview of USGS information products, including maps, imagery, and publications, visit http://store.usgs.gov/.

Any use of trade, firm, or product names is for descriptive purposes only and does not imply endorsement by the U.S. Government.

Although this information product, for the most part, is in the public domain, it also may contain copyrighted materials as noted in the text. Permission to reproduce copyrighted items must be secured from the copyright owner.

Suggested citation:

Boldt, J.A., 2016, Flood-inundation maps for the East Fork White River at Shoals, Indiana: U.S. Geological Survey Scientific Investigations Report 2016-5036, 22 p., http://dx.doi.org/10.3133/sir20165036. 


\section{Acknowledgments}

The author wishes to thank the many local, State, and Federal agencies that have cooperated in the funding for the operation and maintenance of the streamgage used for this study, especially the U.S. Army Corps of Engineers-Louisville District. Special thanks are given to the Indiana Office of Community and Rural Affairs for their cooperation in this study and to the National Weather Service for their continued support of the USGS flood-inundation mapping initiative. 


\section{Contents}

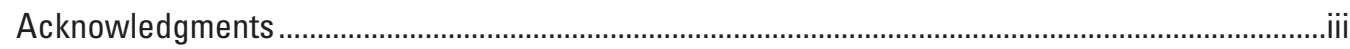

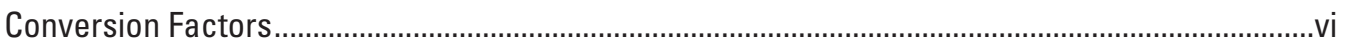

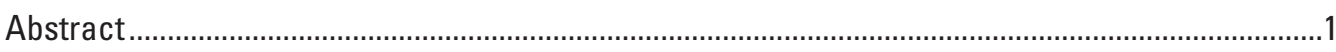

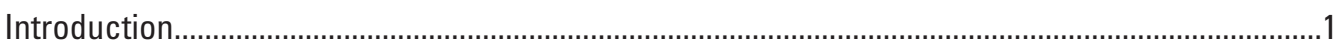

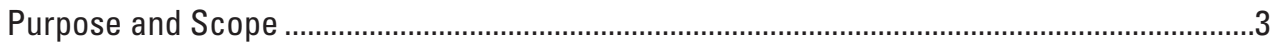

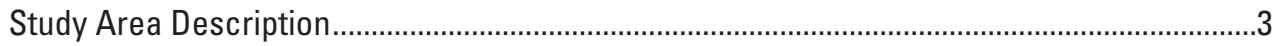

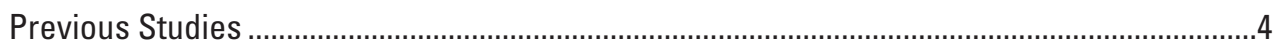

Creation of Flood-Inundation-Map Library ..........................................................................................4

Computation of Water-Surface Profiles....................................................................................

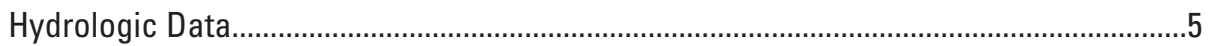

Topographic and Bathymetric Data ...........................................................................

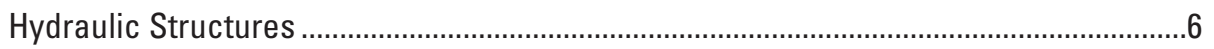

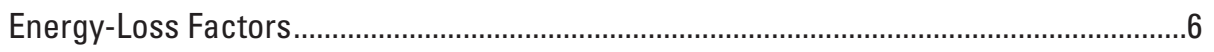

Hydraulic Model........................................................................................................

Development of Water-Surface Profiles...........................................................................

Development of Flood-Inundation Maps ............................................................................8

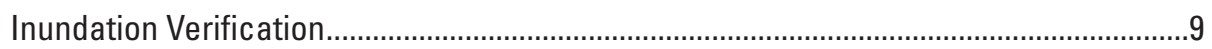

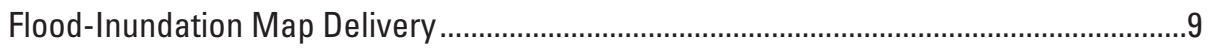

Disclaimer for Flood-Inundation Maps ................................................................................

Uncertainties and Limitations Regarding Use of Flood-Inundation Maps .........................9

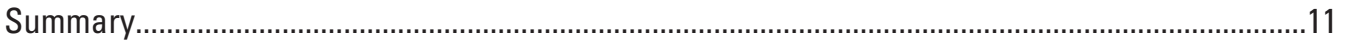

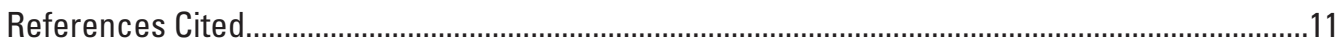

Appendix 1. Supplemental Data and Photographs .......................................................................14 


\section{Figures}

1. Map showing location of study reach for the East Fork White River at Shoals, Indiana; location of U.S. Geological Survey streamgage; and location of National Weather

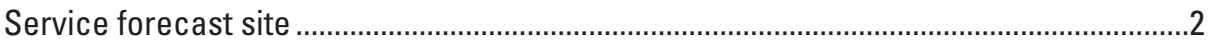

2. Graph showing water-surface profile for the 5.9-mi study reach of the East Fork White River at Shoals, Indiana, corresponding to a discharge with an annual exceedance probability of 10 percent....................................................................................................

3. Map showing flood-inundation map for the East Fork White River at Shoals, Indiana, corresponding to a stage of 35 feet at the U.S. Geological Survey streamgage

\section{Tables}

1. U.S. Geological Survey streamgage information for the East Fork White River at Shoals, Indiana (station number 03373500).

2. Coordinated discharges for selected annual exceedance probabilities for the East Fork White River at Shoals, Indiana

3. Estimated discharges for corresponding stages and water-surface elevations at U.S. Geological Survey streamgage 03373500 used in the hydraulic model of the East Fork White River at Shoals, Indiana

4. Comparison of target water-surface elevations at U.S. Geological Survey streamgage 03373500, East Fork White River at Shoals, Indiana, with water-surface elevations output from the hydraulic model 


\section{Conversion Factors}

U.S. customary units to International System of Units

\begin{tabular}{|c|c|c|}
\hline Multiply & By & To obtain \\
\hline \multicolumn{3}{|c|}{ Length } \\
\hline foot $(\mathrm{ft})$ & 0.3048 & meter $(\mathrm{m})$ \\
\hline mile (mi) & 1.609 & kilometer $(\mathrm{km})$ \\
\hline \multicolumn{3}{|c|}{ Area } \\
\hline square mile $\left(\mathrm{mi}^{2}\right)$ & 2.590 & square kilometer $\left(\mathrm{km}^{2}\right)$ \\
\hline \multicolumn{3}{|c|}{ Flow rate } \\
\hline cubic foot per second $\left(\mathrm{ft}^{3} / \mathrm{s}\right)$ & 0.02832 & cubic meter per second $\left(\mathrm{m}^{3} / \mathrm{s}\right)$ \\
\hline \multicolumn{3}{|c|}{ Hydraulic gradient } \\
\hline foot per mile (ft/mi) & 0.1894 & meter per kilometer $(\mathrm{m} / \mathrm{km})$ \\
\hline
\end{tabular}

\section{Datum}

Vertical coordinate information is referenced to either (1) stage, the height above an arbitrary datum established at a streamgage; or (2) elevation, the height above the North American Vertical Datum of 1988 (NAVD 88).

Horizontal coordinate information is referenced to the North American Datum of 1983 (NAD 83). 


\title{
Flood-Inundation Maps for the East Fork White River at Shoals, Indiana
}

\author{
By Justin A. Boldt
}

\section{Abstract}

Digital flood-inundation maps for a 5.9-mile reach of the East Fork White River at Shoals, Indiana (Ind.), were created by the U.S. Geological Survey (USGS) in cooperation with the Indiana Office of Community and Rural Affairs. The flood-inundation maps, which can be accessed through the USGS Flood Inundation Mapping Science Web site at http:// water.usgs.gov/osw/flood_inundation/depict estimates of the areal extent and depth of flooding corresponding to selected water levels (stages) at the USGS streamgage on the East Fork White River at Shoals, Ind. (USGS station number 03373500). Near-real-time stages at this streamgage may be obtained on the Internet from the USGS National Water Information System at http://waterdata.usgs.gov/ or the National Weather Service (NWS) Advanced Hydrologic Prediction Service (AHPS) at http://water.weather.gov/ahps/, which also forecasts flood hydrographs at this site (NWS AHPS site SHLI3). NWS AHPS forecast peak stage information may be used in conjunction with the maps developed in this study to show predicted areas of flood inundation.

Flood profiles were computed for the East Fork White River reach by means of a one-dimensional, step-backwater model developed by the U.S. Army Corps of Engineers. The hydraulic model was calibrated by using the current stage-discharge relation (USGS rating no. 43.0) at USGS streamgage 03373500, East Fork White River at Shoals, Ind. The calibrated hydraulic model was then used to compute 26 water-surface profiles for flood stages at 1-foot (ft) intervals referenced to the streamgage datum and ranging from approximately bankfull (10 ft) to the highest stage of the current stage-discharge rating curve $(35 \mathrm{ft})$. The simulated watersurface profiles were then combined with a geographic information system (GIS) digital elevation model (DEM), derived from light detection and ranging (lidar) data, to delineate the area flooded at each water level. The areal extent of the 24-ft flood-inundation map was verified with photographs from a flood event on July 20, 2015.

The availability of these maps, along with information on the Internet regarding current stage from the USGS streamgage at East Fork White River at Shoals, Ind., and forecasted stream stages from the NWS AHPS, provides emergency management personnel and residents with information that is critical for flood response activities such as evacuations and road closures, as well as for post-flood recovery efforts.

\section{Introduction}

The town of Shoals, Indiana (Ind.), is located in Martin County (fig. 1) and has an estimated population of 756 (U.S. Census Bureau, 2010). Shoals is subject to flooding from the East Fork White River and Beaver Creek. Shoals and the surrounding area have experienced flooding (stage $>20$ feet [ft]) numerous times, most recently in 2005, 2006, 2007, $2008,2011,2012,2014$, and 2015, with six of those events (all but 2012 and 2015) reaching at least a moderate flood stage $(>25 \mathrm{ft})$. The most recent major flood stage $(>30 \mathrm{ft})$ events occurred in 2005, 2008, and 2011. The majority of flood damages in the Shoals area have occurred along the East Fork White River, which flows through the middle of the town. Floodplains along the river are composed mostly of agricultural and forested areas. During flood events, there is significant flooding of surrounding agricultural lands, many local roads become impassable, and some evacuations are necessary.

Prior to this study, emergency responders in Shoals relied on several information sources to make decisions on how to best alert the public and mitigate flood damages. One source is the Federal Emergency Management Agency (FEMA) flood insurance study (FIS) for Martin County (Federal Emergency Management Agency, 2014). A second source of information is U.S. Geological Survey (USGS) streamgage 03373500, East Fork White River at Shoals, Ind., from which current (U.S. Geological Survey, 2015a) and historical (U.S. Geological Survey, 2015b) water levels (stage) and discharges, including annual peak flows, can be obtained (http://waterdata.usgs.gov/ in/nwis/inventory/?site_no $=03373500 \&$ agency_cd=USGS). A third source of flood-related information is the National Weather Service (NWS) Advanced Hydrologic Prediction Service (AHPS), which displays the USGS stage data and also issues forecasts of stage for the East Fork White River at the USGS streamgage (National Weather Service, 2015a). 


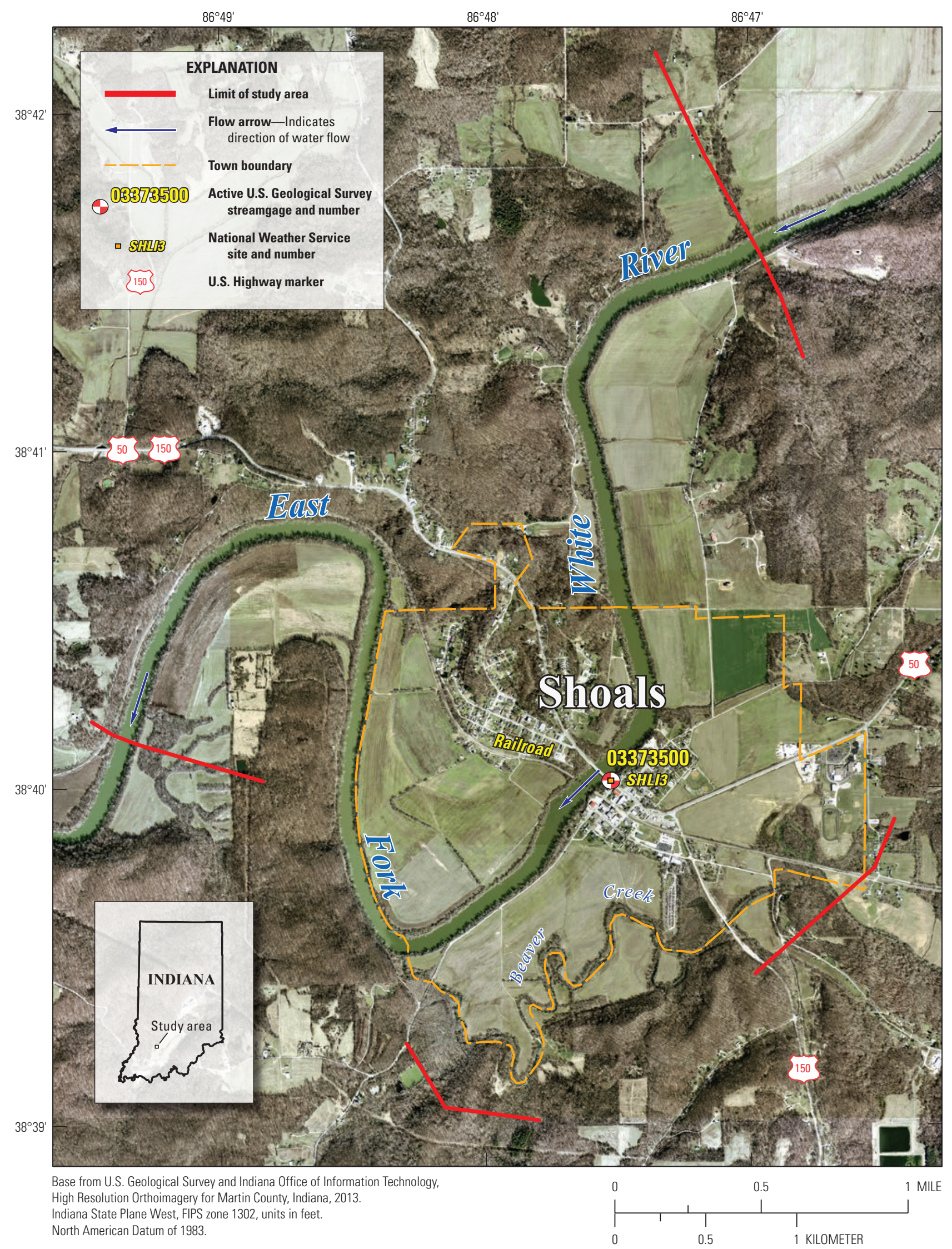

Figure 1. Location of study reach for the East Fork White River at Shoals, Indiana; location of U.S. Geological Survey streamgage (03373500); and location of National Weather Service forecast site (SHLI3). 
Although the current stage at a USGS streamgage and the NWS AHPS flood forecast information are particularly useful for residents in the immediate vicinity of a streamgage, it is generally of limited use to residents farther upstream or downstream because the water-surface elevation is not constant along the entire stream reach. Additionally, knowledge of a water level at a streamgage is difficult to translate into depth and areal extent of flooding at points distant from the streamgage. One way to address these informational gaps is to produce a library of flood-inundation maps that are referenced to the stages recorded at the USGS streamgage. By referring to the appropriate map, emergency responders can discern the severity of flooding (depth of water and areal extent), identify roads that are or will soon be flooded, and make plans for notification or evacuation of residents in harm's way for some distance upstream and downstream from the streamgage. In addition, the capability to visualize the potential extent of flooding has been shown to motivate residents to take precautions and heed warnings that they might have previously disregarded. The USGS, in cooperation with the Indiana Office of Community and Rural Affairs, led a study to produce a library of flood-inundation maps for the East Fork White River at Shoals, Ind.

\section{Purpose and Scope}

This report describes the development of a series of estimated flood-inundation maps for the East Fork White River at Shoals, Ind., and identifies where on the Internet the maps can be accessed and ancillary data (geographic information system [GIS] flood polygons and depth grids) can be downloaded. Internet users can select estimated inundation maps that correspond to (1) flood stages at USGS streamgage 03373500 and (2) the NWS forecasted peak stage at the NWS AHPS site SHLI3. The scope of the study was limited to the East Fork White River reach extending 2.2 miles (mi) upstream and $3.7 \mathrm{mi}$ downstream from USGS streamgage 03373500 at the U.S. Highway 50/150 bridge (fig. 1).

The flood-inundation maps were produced for flood levels referenced to the stage recorded at the USGS streamgage on the East Fork White River at Shoals, Ind. (table 1). The streamgage is on the left bank, $30 \mathrm{ft}$ upstream of the U.S.
Highway $50 / 150$ bridge at Shoals. The maps cover a range in stage from 10 to $35 \mathrm{ft}$, gage datum. The $10-\mathrm{ft}$ stage is approximately bankfull and is defined by the National Weather Service (2015b) as the "action stage" or that stage which, when reached by a rising stream, requires the NWS or a partner to take some type of mitigation action in preparation for possible significant hydrologic activity. The $20-\mathrm{ft}, 25-\mathrm{ft}$, and $30-\mathrm{ft}$ stages are defined by the National Weather Service (2015a) as flood stage, moderate flood stage, and major flood stage, respectively. The $35-\mathrm{ft}$ stage is the highest stage of the current stage-discharge rating curve (U.S. Geological Survey, 2015a) and exceeds the major flood stage as defined by the NWS (National Weather Service, 2015b). Since 1904, there have been only two flood events with crests over $35 \mathrm{ft}$ (the 1913 and 1937 historic floods), and the stage of the most recent major flood event was $33.22 \mathrm{ft}$ on January 11, 2005 (U.S. Geological Survey, 2015c).

\section{Study Area Description}

The East Fork White River near the town of Shoals in Martin County is in southwest Indiana in the Crawford Upland physiographic section of the Southern Hills and Lowlands Region (Gray, 2000). The drainage area is 4,922 square miles $\left(\mathrm{mi}^{2}\right)$ at the upstream end of the study reach; 4,927 $\mathrm{mi}^{2}$ at USGS streamgage 03373500 , East Fork White River at Shoals; and 5,010 $\mathrm{mi}^{2}$ at the downstream end of the study reach (U.S. Geological Survey, 2015b, 2015d). The headwaters originate in Henry County (not shown) and the stream flows generally southward before turning a more westerly direction about $34 \mathrm{mi}$ east-northeast of Shoals. Flow is partially regulated by an upstream reservoir-Monroe Lake (not shown) - which affects the streamflow at Shoals. There are no significant tributaries to the East Fork White River as it flows through the study reach. Minor tributaries within the study reach include (from upstream to downstream) Cedar Brook, Hickory Run, Overlook Drain, Speel Creek, Beaver Creek, and Nubbin Ridge Branch (not shown). The basin terrain is generally bedrock hills of high relief (Gray, 2000). The soil in the study reach is classified as silty, moist soils formed in loess and siltstone, sandstone, and shale; mainly Udalfs, many with fragipans, used for forestry, pasture, and forages (Franzmeier

Table 1. U.S. Geological Survey streamgage information for the East Fork White River at Shoals, Indiana (station number 03373500).

$\left[\mathrm{mi}^{2}\right.$, square miles; NAD 83, North American Datum of 1983; ' , degree; ', minute; ", second; NAVD 88, North American Vertical Datum of 1988; ft, feet; $\mathrm{ft}^{3} / \mathrm{s}$, cubic feet per second]

\begin{tabular}{|c|c|c|c|c|c|c|c|c|}
\hline $\begin{array}{l}\text { Streamgage } \\
\text { name }\end{array}$ & $\begin{array}{c}\text { Streamgage } \\
\text { number }\end{array}$ & $\begin{array}{c}\text { Drainage } \\
\text { area } \\
\left(\mathrm{mi}^{2}\right)\end{array}$ & $\begin{array}{l}\text { Latitude } \\
\text { (NAD 83) }\end{array}$ & $\begin{array}{l}\text { Longitude } \\
\text { (NAD 83) }\end{array}$ & $\begin{array}{l}\text { Datum of } \\
\text { gage } \\
\text { (NAVD 88) }\end{array}$ & Period of record & $\begin{array}{c}\text { Maximum recorded flood } \\
\text { elevation (NAVD 88) and } \\
\text { date }\end{array}$ & $\begin{array}{c}\text { Maximum } \\
\text { discharge }\left(\mathrm{ft}^{3} / \mathrm{s}\right) \\
\text { and date } \\
\end{array}$ \\
\hline $\begin{array}{l}\text { East Fork } \\
\text { White River } \\
\text { at Shoals, } \\
\text { Indiana }\end{array}$ & 03373500 & 4,927 & $38^{\circ} 40^{\prime} 01^{\prime \prime}$ & $86^{\circ} 47^{\prime} 31^{\prime \prime}$ & $441.91 \mathrm{ft}$ & $\begin{array}{l}\text { October } 1903 \text { to } \\
\text { present }(2015)\end{array}$ & $\begin{array}{l}484.11 \mathrm{ft} \text { on March } 28,1913 \\
\text { (corresponds to a gage } \\
\text { height of } 42.20 \mathrm{ft} \text { ) }\end{array}$ & $\begin{array}{l}160,000 \text { on } \\
\text { March 28, } \\
1913\end{array}$ \\
\hline
\end{tabular}


and others, 2004). The bed of the channel near the USGS streamgage at Shoals is ledge rock overlain with broken rock and silt. The study reach is approximately $5.9 \mathrm{mi}$ long and has an average top-of-bank channel width of about $330 \mathrm{ft}$ and an average channel slope of $0.00031(1.6 \mathrm{ft} / \mathrm{mi})$. Most of the land contiguous to the study reach is either agricultural or forested with a small portion that is residentially developed. The population of Shoals has declined in recent years from 807 in 2000 to 756 in 2010 (U.S. Census Bureau, 2010). The main channel and adjacent floodplain within the study reach has one major road crossing (U.S. Highway 50/150) and one railroad crossing (see appendix for photos). The East Fork White River flows into the White River, which flows into the Wabash River, which flows into the Ohio River.

\section{Previous Studies}

The most recent FIS that provides information for the streamgage at the East Fork White River at Shoals is the FIS for Martin County, Indiana (Federal Emergency Management Agency, 2014). This version of the FIS, effective October 2, 2014, includes new studies of streams in Martin County by approximate methods, redelineation of the previously effective flood hazard information, and updates to the format of the Flood Insurance Rate Maps (FIRMs). The hydrologic and hydraulic analyses for the town of Shoals (East Fork White River) were previously performed by the U.S. Army Corps of Engineers (USACE), Louisville District and were completed in 1989; these analyses were documented in the previous FIS, dated May 16, 1995, and were carried forward to the most recent FIS. The East Fork White River was studied by detailed methods using cross section and structural geometry data obtained from field surveys, peak flow information from analysis of the USGS gage at Shoals, and roughness factors from field observations and engineering judgment. The water-surface elevations were computed through the use of the USACE HEC-2 step-backwater computer program, and flood profiles were prepared for the selected recurrence intervals. The FIS presents estimates of the peak discharges with 10,2, 1, and 0.2-percent annual exceedance probabilities for the East Fork White River at Shoals (USGS gage number 03373500); however, it was discovered that the naming of these discharges in the FIS are incorrect and should actually be the 10, 4, 2, and 1-percent annual exceedance probabilities.

The Indiana Department of Natural Resources (IDNR) has produced Digital Flood Insurance Rate Maps (DFIRM), which include the study area in Martin County (Indiana Department of Natural Resources, 2004). These maps outline the special flood hazard areas around Shoals. In addition, the IDNR, the USGS, the Natural Resources Conservation Service, and the USACE have agreed to the discharge-frequency values for sites along many rivers in Indiana; the values are termed coordinated discharges and assure consistency among the State and Federal agencies that undertake streamflow studies (Indiana Department of Natural Resources, 2015). The coordinated discharges for the East Fork White River at Shoals were obtained from the Point Coordination Table for the East Fork White River (Indiana Department of Natural Resources, 2015) and the FIS for Martin County (Federal Emergency Management Agency, 2014) and are listed in table 2. These discharges were determined by a log-Pearson Type III analysis of the USGS gage at Shoals, and the frequency curve was modified to include the effects of Monroe Lake (Federal Emergency Management Agency, 2014).

\section{Creation of Flood-Inundation-Map Library}

The USGS has standardized the procedures for creating flood-inundation maps for flood-prone communities so that the process followed and products produced are similar regardless of which USGS office is responsible for the work (U.S. Geological Survey, 2015e). Tasks specific to the development of the flood maps for Shoals, Ind., were: (1) compilation of flow data from USGS streamgage 03373500, (2) collection of topographic and bathymetric data for selected cross sections and geometric data for structures and bridges along the study reach, (3) estimation of energy-loss factors (roughness

Table 2. Coordinated discharges for selected annual exceedance probabilities for the East Fork White River at Shoals, Indiana.

[mi² , square miles; $\mathrm{ft}^{3} / \mathrm{s}$, cubic feet per second; USGS, U.S. Geological Survey]

\begin{tabular}{|c|c|c|c|c|c|}
\hline \multirow[t]{2}{*}{$\begin{array}{c}\text { Location on East Fork } \\
\text { White River }\end{array}$} & \multirow{2}{*}{$\begin{array}{l}\text { Drainage } \\
\text { area } \\
\left(\mathrm{mi}^{2}\right)\end{array}$} & \multicolumn{4}{|c|}{$\begin{array}{l}\text { Coordinated discharges }\left(\mathrm{ft}^{3} / \mathrm{s}\right) \text { for indicated } \\
\text { annual exceedance probabilities } \\
\text { (in percent) }{ }^{1}\end{array}$} \\
\hline & & 10 & 4 & 2 & 1 \\
\hline $\begin{array}{c}\text { At USGS streamgage } \\
\text { number } 03373500\end{array}$ & 4,927 & 63,500 & 79,200 & 92,000 & 105,300 \\
\hline
\end{tabular}

${ }^{1}$ Data from Indiana Department of Natural Resources (2015). 
coefficients) in the stream channel and floodplain, (4) computation of water-surface profiles by use of the U.S. Army Corps of Engineers' HEC-RAS computer program (U.S. Army Corps of Engineers, 2010), (5) production of estimated floodinundation maps at various stream stages by use of the U.S. Army Corps of Engineers' HEC-GeoRAS computer program (U.S. Army Corps of Engineers, 2011) and a GIS computer program called ArcGIS (Esri, 2015), and (6) preparation of the maps, both as shapefile polygons that depict the areal extent of flood inundation and as depth grids that provide the depth of floodwaters, for display on a USGS flood-inundation mapping application. The USGS provided quality-control reviews of the hydraulic model and its related datasets and resulting floodinundation maps. Methods used are generally cited from previously published reports (Bales and others, 2007; Whitehead and Ostheimer, 2009). If techniques varied significantly from previously documented methods in response to local hydrologic conditions or availability of data, they are described in detail in this report. Twenty-six maps were produced for water levels referenced to the stage at USGS streamgage 03373500 , East Fork White River at Shoals, Ind., and range from approximately bankfull (10 ft) to the highest stage on the current stage-discharge rating curve $(35 \mathrm{ft})$.

\section{Computation of Water-Surface Profiles}

The water-surface profiles used to produce the 26 floodinundation maps in this study were simulated by using HECRAS, version 4.1.0 (U.S. Army Corps of Engineers, 2010). HEC-RAS is a one-dimensional, step-backwater model for simulation of water-surface profiles with gradually varied, steady-state or unsteady-state flow computation options. The HEC-RAS analysis for this study was done using the steadystate flow computation option.

\section{Hydrologic Data}

The study area hydrologic network consists of one streamgage (fig. 1; table 1); USGS streamgage 03373500 has been in operation since October 1, 1903 (water year 1904), and is collocated with the NWS AHPS site SHLI3. This streamgage has a continuous record of measured water level (stage) and computed streamflow. Stage is measured every 15 minutes, transmitted hourly by a satellite radio in the streamgage, and made available on the Internet through the USGS National Water Information System (NWIS; U.S.

Geological Survey, 2015b). Stage data from this streamgage are referenced to a local datum but can be converted to watersurface elevations referenced to the North American Vertical Datum of 1988 (NAVD 88) by adding $441.91 \mathrm{ft}$. Data from this streamgage are used for calibration of the model and comparison of model results.

The steady-flow data necessary for the hydraulic model consisted of boundary conditions (normal depth) and peakdischarge information. The peak flows used in the model simulations (table 3 ) were obtained from the current stagedischarge relation (USGS rating no. 43.0, effective October 1, 2002, and current at the time of this investigation (2015)) for streamgage 03373500 and corresponded with the target stages. All computations used discharge values with known stages from actual streamflow measurements or the stage-discharge relation at the gage. No major tributaries join the East Fork White River within the 5.9-mi study reach; therefore, the gage-derived discharges were not adjusted for tributary inflows but were held constant throughout the study reach for a given profile.

Table 3. Estimated discharges for corresponding stages and water-surface elevations at U.S. Geological Survey streamgage 03373500 used in the hydraulic model of the East Fork White River at Shoals, Indiana.

[ft, feet; NAVD 88, North American Vertical Datum of 1988; USGS, U.S. Geological Survey; $\mathrm{ft}^{3} / \mathrm{s}$, cubic feet per second]

\begin{tabular}{ccc}
\hline $\begin{array}{c}\text { Stage } \\
\text { (ft above gage } \\
\text { reference datum) }\end{array}$ & $\begin{array}{c}\text { Water-surface } \\
\text { elevation } \\
\text { (ft, NAVD 88) }\end{array}$ & $\begin{array}{c}\text { Estimated discharge at USGS } \\
\text { streamgage number 03373500 } \\
\text { (ft } \mathbf{3} / \mathbf{s})\end{array}$ \\
\hline 10.00 & 451.91 & 15,000 \\
11.00 & 452.91 & 16,500 \\
12.00 & 453.91 & 17,900 \\
13.00 & 454.91 & 19,300 \\
14.00 & 455.91 & 20,700 \\
15.00 & 456.91 & 22,000 \\
16.00 & 457.91 & 23,600 \\
17.00 & 458.91 & 25,100 \\
18.00 & 459.91 & 27,000 \\
19.00 & 460.91 & 29,000 \\
20.00 & 461.91 & 31,000 \\
21.00 & 462.91 & 33,000 \\
22.00 & 463.91 & 35,000 \\
23.00 & 464.91 & 37,100 \\
24.00 & 465.91 & 40,000 \\
25.00 & 466.91 & 43,000 \\
26.00 & 467.91 & 46,000 \\
27.00 & 468.91 & 49,400 \\
28.00 & 469.91 & 53,100 \\
29.00 & 470.91 & 57,000 \\
30.00 & 471.91 & 61,000 \\
31.00 & 472.91 & 65,500 \\
32.00 & 473.91 & 70,400 \\
33.00 & 474.91 & 75,500 \\
34.00 & 475.91 & 80,800 \\
35.00 & 476.91 & 86,300 \\
\hline & &
\end{tabular}


Flood-Inundation Maps for the East Fork White River at Shoals, Indiana

\section{Topographic and Bathymetric Data}

All topographic data used in this study are referenced vertically to NAVD 88 and horizontally to the North American Datum of 1983 (NAD 83). Cross-section elevation data were obtained from a digital elevation model (DEM) that was derived from light detection and ranging (lidar) data that were collected as part of a statewide project during 2011-13 by Woolpert, Inc., Geospatial Services, Dayton, Ohio (Woolpert, Inc., 2011). The lidar data for Martin County was collected in 2013. The DEM was obtained from the Indiana Spatial Data Portal (Indiana University, 2013). The original lidar data have a horizontal resolution of $4.9 \mathrm{ft}$ and a vertical accuracy of $0.98 \mathrm{ft}$ at a 95 -percent confidence level based on a root mean squared error of $0.49 \mathrm{ft}$ for the "open terrain" land-cover category. By these criteria, the lidar data support production of 2-ft contours (Dewberry, 2012); the final DEM, which was kept at its original grid-cell size of $5 \mathrm{ft}$ by $5 \mathrm{ft}$, has a vertical accuracy of plus or minus $1 \mathrm{ft}$.

Because lidar data cannot provide ground elevations below a stream's water surface, channel cross sections were surveyed by USGS field crews during April 2013. Cross-sectional depths were measured by using hydroacoustic instrumentation at 18 locations along the study reach. A differential global positioning system (DGPS) with real-time kinematic (RTK) technology was used to derive horizontal locations and the elevation of the water surface at each surveyed cross section.

In the ArcMap (version 10.0) application of ArcGIS (Esri, 2015), these field data were used in conjunction with a bathymetry mesh tool, created by Merwade and others (2008), to interpolate below-water ground elevations through the study reach. The density of ground elevations in the mesh was determined by two variables: (1) the number of parallel longitudinal profiles that were evenly spaced across the channel and ran the length of the study reach and (2) the user-specified spacing between cross sections. Ground elevations were either extracted or interpolated from the field data at the intersections of the longitudinal profiles and cross sections that were spaced approximately $100 \mathrm{ft}$ apart. Instructions for the bathymetry mesh tool are presented by Merwade (2011).

The mesh elevations were then merged with ("burned" or "carved" into) the DEM data, resulting in a merged DEM (overbank and in-channel elevations). By using HEC-GeoRAS (a set of procedures, tools, and utilities for processing geospatial data in ArcGIS), elevation data were extracted from the merged DEM for 63 cross sections at desired locations along the study reach. These data subsequently were input to the HEC-RAS model.

\section{Hydraulic Structures}

Various man-made structures (bridges, culverts, and roadway embankments) in and along the East Fork White River affect or have the potential to affect water-surface elevations during floods along the stream. To properly account for these features in the model, structural dimensions for two bridges (U.S. Highway 50/150 and a railroad bridge) were obtained from field surveys conducted by USGS personnel in April 2013. Culvert locations were confirmed in a field survey conducted by the author in July 2015; this was needed to aid in determining whether disconnected flood-inundation areas were actually connected with the main river or just low areas in the topography.

The station description for the USGS streamgage at Shoals notes that all flow is confined to the highway bridge except for bypassing water at stages above $26.5 \mathrm{ft}$. At stages above $26.5 \mathrm{ft}$, some of the flow bypasses to the east of the town through an 8 -ft by 8 -ft box culvert under U.S. Highway 50 about $1,200 \mathrm{ft}$ east of the junction with U.S. Highway 150 . This flow continues through a 6.5 -ft diameter culvert through the B\&O Railroad fill and then joins with Beaver Creek. The bypassing water continues through a bridge over Beaver Creek at U.S. Highway 150 and is then reconnected with the East Fork White River near the meander bend southwest of Shoals. The hydraulic structures in the floodplain were not represented in the model, which likely had a negligible effect on the water surface elevation at the USGS gage. These structures primarily serve to allow floodwater stored in the floodplain to drain back to the East Fork White River.

\section{Energy-Loss Factors}

Hydraulic analyses require the estimation of energy losses that result from frictional resistance exerted by a channel on the flow. These energy losses are quantified by the Manning's roughness coefficient ( $n$-value) (Arcement and Schneider, 1989). Initial (precalibration) $n$-values were selected on the basis of field observations, high-resolution aerial photographs, and the most recent FIS. An $n$-value of 0.051 was selected for the main channel because it has a low-gradient, rocky, and silty bed with irregular banks typical of natural streams, occasional variation in cross section, negligible inchannel obstructions, tree-lined banks, and moderate to severe meandering. The overbank areas have mixed land uses but are dominated by agricultural fields and forests. The town of Shoals consists of densely populated residential and commercial areas that border the East Fork White River on both sides, but these areas are mostly on elevated ground. Just upstream of Shoals and to the upstream limit of the study reach, the left overbank is primarily agricultural and the right overbank is primarily forest. Just downstream of Shoals, both the left and the right overbanks are agricultural. After the first meander bend downstream of Shoals, there is a mixture of agricultural and forested land. All of the agricultural land that borders the East Fork White River has a dense line of trees between the fields and the river. An $n$-value of 0.08 was selected for the primarily agricultural overbank areas, and an $n$-value of 0.16 was selected for the primarily forested overbank areas.

The initial $n$-values were adjusted as part of the calibration process, which involved minimizing the differences (within $\pm 0.50 \mathrm{ft}$ ) between simulated and observed 
water-surface elevations at the streamgage in the study reach. Roughness-coefficient adjustment factors (flow roughness factors) are a feature that allows the specified $n$-values to adjust with changes in flow. This option was used minimally until the simulated water-surface elevations were within the allowable range for the target water-surface elevations. Flow roughness factors were only needed for the lowest seven stages modeled (10-16 ft). This factor was 0.84 for the $10-\mathrm{ft}$ stage and increased fairly uniformly to 1.0 at the 17 -ft stage; the other modeled stages (17-35 ft) kept the default flow roughness factor of 1.0. The likely explanation for the flowroughness factors is that the thick line of vegetation and trees at the top of the banks and just overbank do not have as much of an effect at the lower stages; the channel is fairly clear of obstructions and vegetation until the dense tree line. Similarly, the lower stages are fairly contained within the banks and are not sufficiently up into the tree line. Thus, the $n$-value for the main channel at lower stages is less than the initial $n$-value and gradually increases as the water surface rises up into the tree line. The actual $n$-values were computed by multiplying the initial $n$-value by each of the roughness-coefficient adjustment factors. Main channel $n$-values ranged from 0.043 to 0.051 , and overbank $n$-values ranged from 0.067 to 0.08 for primarily agricultural areas and from 0.13 to 0.16 for primarily forested areas.

\section{Hydraulic Model}

The hydraulic analysis for this study was done using HEC-RAS with the steady-state flow computation option. Steady-state flow data consisted of flow regime, boundary conditions, and peak flows that produced water-surface elevations at the streamgage cross section that matched target water-surface elevations within $\pm 0.50 \mathrm{ft}$ of the current rating for streamgage 03373500 . These target elevations coincided with even 1-ft increments of stage, referenced to the local gage datum. Subcritical (tranquil) flow regime was assumed for the simulations. Normal depth, based on an estimated average water-surface slope of 0.00031 , was used as the reach's downstream boundary condition. This slope was calculated as the average channel-bed slope between the downstream cross section and the next three sequential cross sections upstream and, coincidentally, is also the computed channel-bed slope for the overall reach. Steady flow was the upstream boundary condition, and the peak flows that were used in the model were discussed in the "Hydrologic Data" section.

The HEC-RAS model was calibrated to the current stage-discharge relation (USGS rating no. 43.0) at USGS streamgage 03373500, East Fork White River at Shoals, Ind. Model calibration was accomplished by adjusting Manning's $n$-values until the results of the hydraulic computations closely agreed with the observed water-surface elevations for given flows. Differences between target and simulated water-surface elevations for the 26 simulated flows at USGS streamgage 03373500 were less than or equal to $0.48 \mathrm{ft}$ (table 4 ). The results demonstrate that the model is capable of simulating reasonable water levels over a wide range of flows at the streamgage.

\section{Development of Water-Surface Profiles}

The calibrated hydraulic model was used to generate water-surface profiles corresponding to flows for a total of 26 stages at 1 - $\mathrm{ft}$ intervals ranging from $10 \mathrm{ft}$ to $35 \mathrm{ft}$ as referenced to USGS streamgage 03373500 . These stages correspond to elevations between $451.91 \mathrm{ft}$ and $476.91 \mathrm{ft}$, NAVD 88, respectively. Discharges corresponding to the

Table 4. Comparison of target water-surface elevations at U.S. Geological Survey streamgage 03373500, East Fork White River at Shoals, Indiana, with water-surface elevations output from the hydraulic model.

[ft, feet; NAVD 88, North American Vertical Datum of 1988]

\begin{tabular}{|c|c|c|c|}
\hline $\begin{array}{c}\text { Stage } \\
\text { (ft) }\end{array}$ & $\begin{array}{c}\text { Target water- } \\
\text { surface elevation } \\
\text { (ft, NAVD 88) }\end{array}$ & $\begin{array}{l}\text { Modeled water- } \\
\text { surface elevation } \\
\text { (ft, NAVD 88) }\end{array}$ & $\begin{array}{c}\text { Elevation } \\
\text { difference } \\
\text { (ft) }\end{array}$ \\
\hline 10.00 & 451.91 & 452.39 & 0.48 \\
\hline 11.00 & 452.91 & 453.34 & 0.43 \\
\hline 12.00 & 453.91 & 454.30 & 0.39 \\
\hline 13.00 & 454.91 & 455.30 & 0.39 \\
\hline 14.00 & 455.91 & 456.25 & 0.34 \\
\hline 15.00 & 456.91 & 457.20 & 0.29 \\
\hline 16.00 & 457.91 & 458.19 & 0.28 \\
\hline 17.00 & 458.91 & 459.12 & 0.21 \\
\hline 18.00 & 459.91 & 460.04 & 0.13 \\
\hline 19.00 & 460.91 & 460.97 & 0.06 \\
\hline 20.00 & 461.91 & 461.88 & -0.03 \\
\hline 21.00 & 462.91 & 462.76 & -0.15 \\
\hline 22.00 & 463.91 & 463.63 & -0.28 \\
\hline 23.00 & 464.91 & 464.51 & -0.40 \\
\hline 24.00 & 465.91 & 465.69 & -0.22 \\
\hline 25.00 & 466.91 & 466.85 & -0.06 \\
\hline 26.00 & 467.91 & 467.75 & -0.16 \\
\hline 27.00 & 468.91 & 468.97 & 0.06 \\
\hline 28.00 & 469.91 & 470.06 & 0.15 \\
\hline 29.00 & 470.91 & 471.02 & 0.11 \\
\hline 30.00 & 471.91 & 471.99 & 0.08 \\
\hline 31.00 & 472.91 & 473.07 & 0.16 \\
\hline 32.00 & 473.91 & 474.00 & 0.09 \\
\hline 33.00 & 474.91 & 474.89 & -0.02 \\
\hline 34.00 & 475.91 & 475.81 & -0.10 \\
\hline 35.00 & 476.91 & 476.72 & -0.19 \\
\hline
\end{tabular}


various stages were obtained from the current stage-discharge relation (USGS rating no. 43.0) at the East Fork White River streamgage. Discharges for all profiles (table 3 ) were selected with the assumption that there are no significant tributary inflows within the 5.9-mi modeled reach. The discharges were estimated to be uniform and steady throughout the modeled reach. Four additional water-surface profiles were generated corresponding to the coordinated discharges for selected annual exceedance probabilities (table 2). This allowed for a comparison to be made between the water-surface profiles generated in this study (labeled as current study model) and the water-surface profiles shown in the FIS for the East Fork White River (fig. 2). The field data that were collected in this study provide a much more detailed representation of the streambed than the FIS. The limits in this study also extend farther downstream and upstream than the FIS. The water-surface profiles for the 10-yr flow compare well-the difference in water surface elevation (WSE) for the FIS 10-yr flow when compared to the WSE for the HEC-RAS 10-yr flow ranges from $0.83 \mathrm{ft}$ to $-0.49 \mathrm{ft}$. At the gage (U.S. Highway 50/150 bridge), the difference in WSE is $-0.03 \mathrm{ft}$. The other three water-surface profiles are not shown because of a suspected error in the FIS. Additional water-surface profiles can be found in the appendix (fig. 1-2).

\section{Development of Flood-Inundation Maps}

Flood-inundation maps were created for a reach of the East Fork White River at Shoals, Ind. The maps were created in a GIS by combining the 26 water-surface profiles and DEM data. The DEM data were derived from the same lidar data described previously in the "Topographic and Bathymetric Data" section and therefore have an estimated vertical accuracy of $2 \mathrm{ft}$ (i.e., plus or minus $1 \mathrm{ft}$ ). Estimated flood-inundation boundaries for each simulated profile were developed with HEC-GeoRAS software (U.S. Army Corps of Engineers, 2011), which allows the preparation of geometric data for import into HEC-RAS and processes simulation results exported from HEC-RAS (U.S. Army Corps of Engineers, 2010). Shapefile polygons and depth grids of the inundated areas for each profile were modified, as required, in the ArcMap application of ArcGIS to ensure a hydraulically reasonable transition of the flood boundaries between model cross sections (Whitehead and Ostheimer, 2009). The resulting inundation maps have a vertical accuracy of about plus or minus $1.0 \mathrm{ft}$.

Any inundated areas that were detached from the main channel were examined to identify subsurface connections with the main river, such as through culverts under roadways.

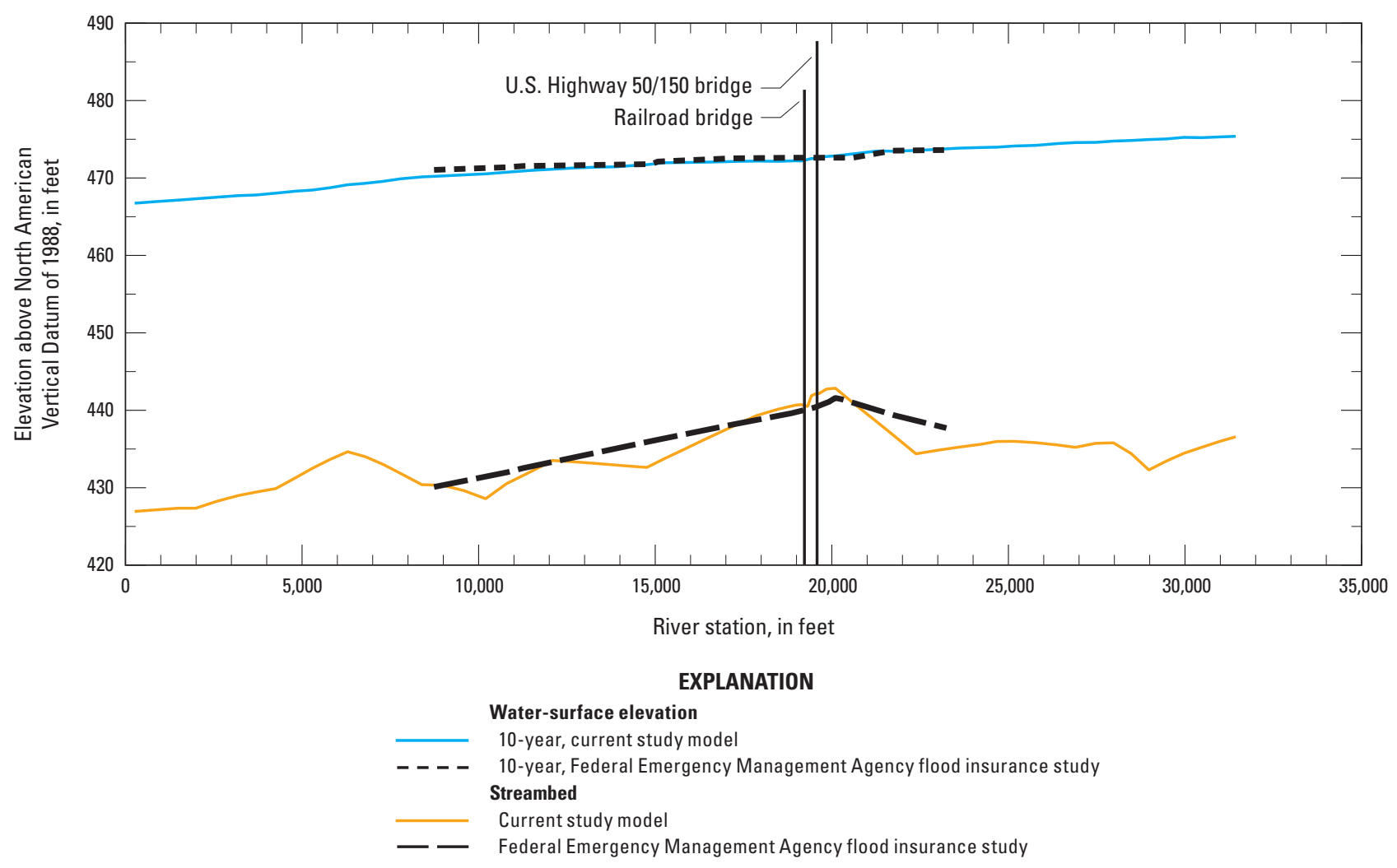

Figure 2. Water-surface profile for the 5.9-mi study reach of the East Fork White River at Shoals, Indiana, corresponding to a discharge with an annual exceedance probability of 10 percent. 
Culvert locations were confirmed in a field survey conducted by the author in July 2015. Where such connections existed, the mapped inundated areas were retained in their respective flood maps; otherwise, the erroneously delineated parts of the flood extent were deleted. The flood-inundation areas are overlaid on high-resolution, georeferenced aerial photographs of the study area. Bridge surfaces are displayed as inundated regardless of the actual water-surface elevation in relation to the lowest structural chord of the bridge or the bridge deck.

Estimates of water depth can be obtained from the depthgrid data that are included with the presentation of the flood maps on an interactive USGS mapping application described in the following section, "Flood-Inundation Map Delivery." The flood-inundation map corresponding to the highest simulated water-surface profile, a stage of $35 \mathrm{ft}$, is presented in figure 3 .

\section{Inundation Verification}

A flood event occurred shortly after the completion of the flood-inundation map library and while this report was in preparation. The East Fork White River had a crest of $24.27 \mathrm{ft}$ (40,800 cubic feet per second [ $\left.\mathrm{ft}^{3} / \mathrm{s}\right]$ ) on July 20, 2015 (U.S. Geological Survey, 2015b). This was also the peak flow for water year 2015. These data are provisional and subject to revision until they have been thoroughly reviewed and received final approval. A visual field survey was conducted on July 20, 2015, with the 24-ft flood-inundation map that was developed for this study. The gage height during the field survey ranged from 24.07-24.24 ft. The primary purpose of the field survey was to spot check the extent of the flooding at various points along public roads throughout the study reach. Overall, there was good agreement between the 24-ft flood-inundation map and the flood extent on July 20, 2015. Documentation comparing the 24-ft flood-inundation map with photographs of water over roads throughout the study reach is shown in the appendix (figs. 1-5-1-15).

\section{Flood-Inundation Map Delivery}

The flood-inundation maps from this study depict estimates of the areal extent and depth of flooding corresponding to selected water levels (stages) at USGS streamgage 03373500, East Fork White River at Shoals, Ind. The current study documentation is available online at the USGS Publications Warehouse (http://pubs.er.usgs.gov/publication/ sir20165036). Also, a Flood Inundation Mapping Science Web site (U.S. Geological Survey, 2015e) has been established to make USGS flood-inundation study information to the public; that site links to a mapping application (http://wim.usgs.gov/ FIMI/FloodInundationMapper.html) that presents map libraries and provides detailed information on flood extent and depths for selected sites. The mapping application enables the production of customized flood-inundation maps from the map library for the East Fork White River at Shoals, Ind. A link on the map library Web site connects to the USGS NWIS (U.S. Geological
Survey, 2015a), which presents the current stage and streamflow at USGS streamgage 03373500 to which the floodinundation maps are referenced. A second link connects to the NWS AHPS site (National Weather Service, 2015a) so that the user can obtain applicable information on forecasted peak stage. The estimated flood-inundation maps are displayed in sufficient detail so that preparations for flooding and decisions for emergency response can be performed efficiently. Depending on the flood magnitude, roadways are shown as shaded (inundated and likely impassable) or not shaded (dry and passable) to facilitate emergency planning and use. Bridges are shaded - that is, shown as inundated - regardless of the flood magnitude. A shaded building should not be interpreted to mean that the structure is completely submerged, but rather that bare earth surfaces in the vicinity of the building are inundated. In these instances, the water depth (as indicated in the mapping application by holding the cursor over an inundated area) near the building would be an estimate of the water level inside the structure, unless flood-proofing measures had been implemented.

\section{Disclaimer for Flood-Inundation Maps}

The flood-inundation maps should not be used for navigation, regulatory, permitting, or other legal purposes. The USGS provides these maps "as-is" for a quick reference, emergency planning tool but assumes no legal liability or responsibility resulting from the use of this information.

\section{Uncertainties and Limitations Regarding Use of Flood-Inundation Maps}

Although the flood-inundation maps represent the boundaries of inundated areas with a distinct line, some uncertainty is associated with these maps (Bales and Wagner, 2009). The flood boundaries shown were estimated on the basis of water stages and streamflows at a single USGS streamgage. Watersurface elevations along the stream reach were estimated by steady-state hydraulic modeling, assuming unobstructed flow, and using streamflows and hydrologic conditions anticipated at the USGS streamgage. The hydraulic model reflects the land-cover characteristics and any bridge, dam, levee, or other hydraulic structures existing as of April 2013. Unique meteorological factors (timing and distribution of precipitation) may cause actual streamflows along the modeled reach to vary from those assumed during a flood, which may lead to deviations in the water-surface elevations and inundation boundaries shown. Additional areas may be flooded because of unanticipated conditions such as changes in the streambed elevation or roughness, backwater into major tributaries along a main-stem river, or backwater from localized debris or ice jams. The accuracy of the floodwater extent portrayed on these maps will vary with the accuracy of the DEM used to simulate the land surface. 


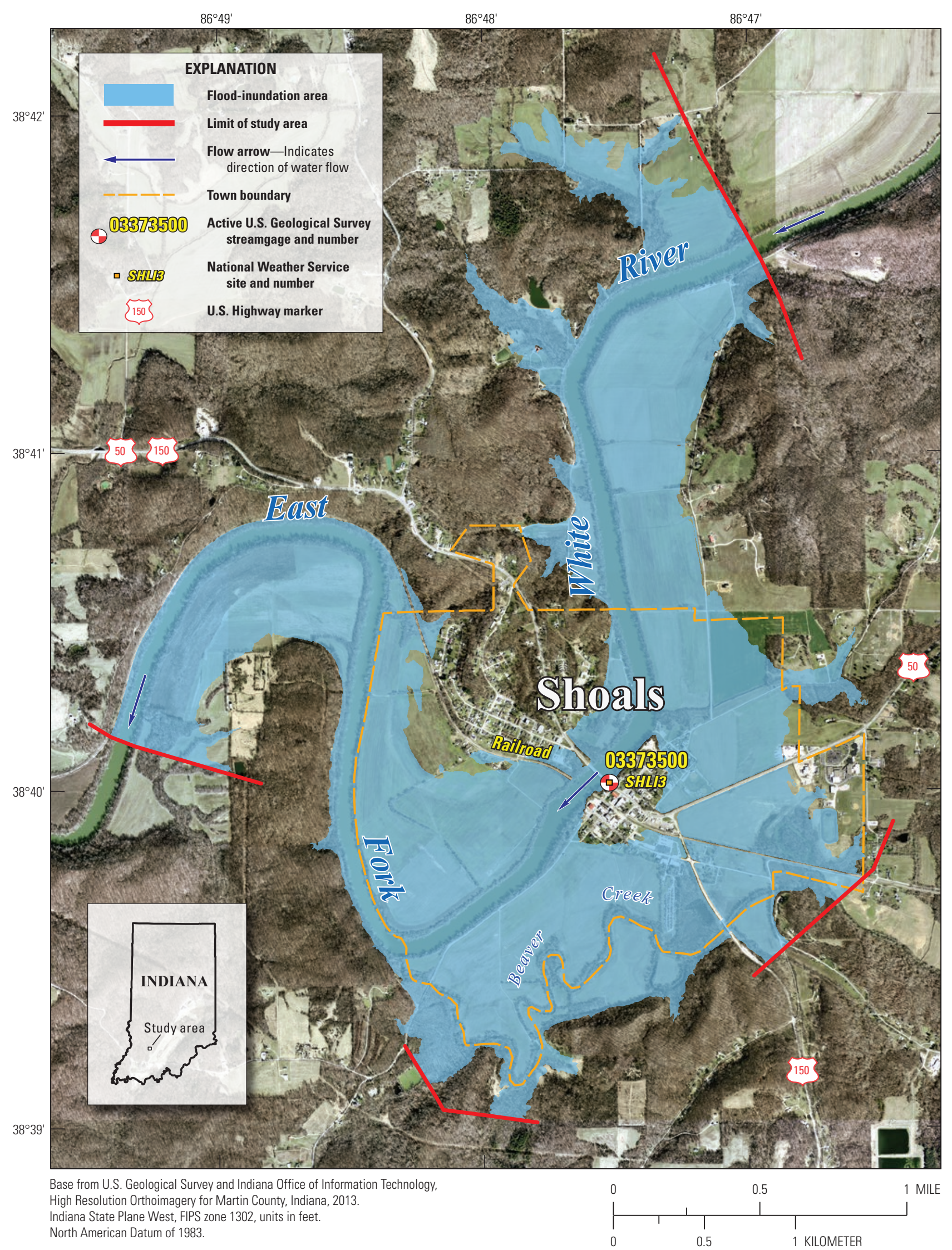

Figure 3. Flood-inundation map for the East Fork White River at Shoals, Indiana, corresponding to a stage of 35 feet at the U.S. Geological Survey streamgage (station number 03373500). 
If this series of flood-inundation maps will be used in conjunction with NWS river forecasts, the user should be aware of additional uncertainties that may be inherent or factored into NWS forecast procedures. The NWS uses forecast models to estimate the quantity and timing of water flowing through selected stream reaches in the United States. These forecast models (1) estimate the amount of runoff generated by precipitation and snowmelt, (2) simulate the movement of floodwater as it proceeds downstream, and (3) predict the flow and stage (and water-surface elevation) for the stream at a given location (AHPS forecast point) throughout the forecast period (every 6 hours and 3 to 5 days out in many locations). For more information on AHPS forecasts, please refer to http://water.weather.gov/ahps/forecasts.php. Additional uncertainties and limitations pertinent to this study may be described elsewhere in this report.

\section{Summary}

A series of 26 digital flood-inundation maps were developed in cooperation with the Indiana Office of Community and Rural Affairs for the East Fork White River at Shoals, Ind., extending $2.2 \mathrm{mi}$ upstream and $3.7 \mathrm{mi}$ downstream from USGS streamgage 03373500 at the U.S. Highway 50/150 bridge. The flood-inundation maps were developed by using the U.S. Army Corps of Engineers' HEC-RAS and HECGeoRAS programs to compute water-surface profiles and to delineate estimated flood-inundation areas and depths of flooding for selected stream stages. The HEC-RAS hydraulic model was calibrated to the current stage-discharge relation (USGS rating no. 43.0) at the East Fork White River streamgage at Shoals. The model was used to compute 26 water-surface profiles for flood stages at 1-ft intervals referenced to the streamgage datum and ranging from approximately bankfull (10 ft) to the highest stage of the current stage-discharge rating curve (35 ft). The simulated water-surface profiles were then combined with a geographic information system DEM derived from lidar data to delineate estimated flood-inundation areas as shapefile polygons and depth grids for each profile. These flood-inundation polygons were overlaid on high-resolution, georeferenced aerial photographs of the study area. The flood maps show estimated (shaded) flood-inundation areas of the study area for stream stages from $10 \mathrm{ft}$ to $35 \mathrm{ft}$ at the East Fork White River at Shoals streamgage. The flood maps are available through a mapping application that can be accessed on the USGS Flood Inundation Mapping Science Web site (http:// water.usgs.gov/osw/flood_inundation).

Interactive use of the maps on the USGS mapping application can give users a general indication of depth of water at any point by using the mouse cursor to click within the shaded areas. The mapping application enables the production of customized flood-inundation maps from the map library for the East Fork White River at Shoals, Ind. These maps, in conjunction with the near-real-time stage data from the USGS streamgage 03373500 and NWS AHPS flood-stage forecasts, will help to guide the general public in taking individual safety precautions and will provide emergency management personnel with a tool to efficiently manage emergency flood operations and post-flood recovery efforts.

\section{References Cited}

Arcement, G.J., and Schneider, V.R., 1989, Guide for selecting Manning's roughness coefficients for natural channels and flood plains: U.S. Geological Survey Water-Supply Paper 2339, 38 p.

Bales, J.D., and Wagner, C.R., 2009, Sources of uncertainty in flood inundation maps: Journal of Flood Risk Management, 2, p. 139-147.

Bales, J.D., Wagner, C.R., Tighe, K.C., and Terziotti, S., 2007, LiDAR-derived flood-inundation maps for real-time floodmapping applications, Tar River Basin, North Carolina: U.S. Geological Survey Scientific Investigations Report 2007-5032, 42 p.

Dewberry, 2012, National enhanced elevation assessment: Fairfax, Va., 84 p., accessed July 2015 at http://www. dewberry.com/docs/default-source/documents/neea_finalreport_revised-3-29-12.pdf.

Esri, 2015, ArcGIS, accessed March 2015 at http://www.esri. com/software/arcgis/.

Franzmeier, D.P., Schulze, D., and Stainhardt, G.C., 2004, Indiana soil and landscape evaluation manual, version 1.0, AY-323: Purdue University Cooperative Extension Service, West Lafayette, In., 81 p.

Federal Emergency Management Agency, 2014, Flood insurance study, Martin County, Indiana, and incorporated areas: Washington, D.C., 20 p.

Gray, H.H., 2000, Physiographic divisions of Indiana: Indiana Geological Survey Special Report 61, Bloomington, In., 15 p., 1 pl.

Indiana Department of Natural Resources, 2004, Digital flood insurance rate maps for Martin County, accessed July 2015 at http://www.in.gov/dnr/water/6474.htm.

Indiana Department of Natural Resources, 2015, Coordinated discharges of selected streams in Indiana, accessed July 2015 at http://www.in.gov/dnr/water/4898.htm.

Indiana University, 2013, Indiana spatial data portal, accessed March 2015 at http://gis.iu.edu/ 
Merwade, V., 2011, Creating river bathymetry mesh from cross-sections: Purdue University, School of Civil Engineering, accessed March 2015 at http://web.ics.purdue. edu/ vmerwade/research/bathymetry_tutorial.pdf.

Merwade, V., Cook, A., and Coonrod, J., 2008, GIS techniques for creating river terrain models for hydrodynamic modeling and flood inundation mapping: Environmental Modelling and Software, v. 23, no. 10-11, p. 1300-1311.

National Weather Service, 2015a, Advanced Hydrologic Prediction Service, East Fork White River at Shoals, Indiana (SHLI3), accessed July 2015 at http://water.weather.gov/ ahps2/hydrograph.php?wfo=ind\&gage=SHLI3 .

National Weather Service, 2015b, National Weather Service glossary, accessed July 2015 at http://w1.weather.gov/glossary/.

U.S. Army Corps of Engineers, Hydrologic Engineering Center, 2010, HEC-RAS river analysis system, hydraulic reference manual, version 4.1 [variously paged], accessed March 2015 at http://www.hec.usace.army.mil/software/hec-ras/ documentation/HEC-RAS_4.1_Reference_Manual.pdf.

U.S. Army Corps of Engineers, Hydrologic Engineering Center, 2011, HEC-GeoRAS, GIS tools for support of HEC-RAS using ArcGIS, user's manual [variously paged], accessed March 2015 at http://www.hec.usace.army.mil/ software/hec-georas/documentation/HEC-GeoRAS_43 Users_Manual.pdf.

U.S. Census Bureau, 2010, Profile of general population and housing characteristics, 2010 demographic profile data for Shoals town, Indiana: Washington, D.C., accessed July 2015 at http://factfinder.census.gov/faces/nav/jsf/pages/ index.xhtml.

U.S. Geological Survey, 2015a, USGS 03373500, East Fork White River at Shoals, Indiana: U.S. Geological Survey, accessed July 2015 at http://waterdata.usgs.gov/in/nwis/ uv?site_no $=03373500$.

U.S. Geological Survey, 2015b, USGS surface-water data for the Nation: U.S. Geological Survey, accessed July 2015 at http://waterdata.usgs.gov/in/nwis/inventory/?site_ no=03373500\&agency_cd=USGS.

U.S. Geological Survey, 2015c, Peak streamflow for the Nation, USGS 03373500 East Fork White River at Shoals, Indiana: U.S. Geological Survey, accessed July 2015 at http:/nwis.waterdata.usgs.gov/usa/nwis/peak/?site no $=03373500$.

U.S. Geological Survey, 2015d, StreamStats version 3 beta, Indiana: U.S. Geological Survey, accessed July 2015 at http://streamstatsags.cr.usgs.gov/v3_beta/viewer. htm?stabbr=IN.
U.S. Geological Survey, 2015e, USGS flood inundation mapping science: U.S. Geological Survey, accessed March 2015 at http://water.usgs.gov/osw/flood_inundation.

Woolpert, Inc., 2011, Woolpert Order No. 71177, Indiana Statewide Imagery and LiDAR Program, remote sensing image: Dayton, Oh., metadata available at http://gis.iu.edu/ files/documents/in2011_ortho.txt.

Whitehead, M.T., and Ostheimer, C.J., 2009, Development of a flood-warning system and flood-inundation mapping for the Blanchard River in Findlay, Ohio: U.S. Geological Survey Scientific Investigations Report 2008-5234, 9 p. 


\section{Appendix 1}

Supplemental Data and Photographs 


\section{Appendix 1. Supplemental Data and Photographs}

Peak streamflow (and stage) data for the East Fork White River at Shoals extends back to water year 1904 (fig. 1-1). The data for 2015 are provisional and subject to revision until they have been thoroughly reviewed and received final approval. From water year 1904-2015, the annual peak streamflow has occurred 80.4 percent of the time between the months of January-May and the mean monthly flow is highest in March (U.S. Geological Survey, 2015c). Peak streamflow since 1963 has been affected by regulation at an upstream reservoir (Monroe Lake).

The calibrated hydraulic model was used to generate water-surface profiles corresponding to flows for a total of 26 stages at 1 - $\mathrm{ft}$ intervals from $10 \mathrm{ft}$ to $35 \mathrm{ft}$ as referenced to USGS streamgage 03373500 . These stages correspond to elevations of $451.91 \mathrm{ft}$ and $476.91 \mathrm{ft}$, NAVD 88 , respectively. Water-surface profiles for the lowest $(10 \mathrm{ft})$ and the highest (35 ft) stages modeled are shown in figure 1-2.

Selected photographs from the field surveys are described below. Figure 1-3 shows the upstream side of the U.S. Highway 50/150 bridge, taken from the left bank. USGS streamgage 03373500 is visible on the left bank. Figure 1-4 shows the upstream side of the railroad bridge, taken from the U.S Highway 50/150 bridge.
A visual field survey was conducted on July 20, 2015, with the 24-ft flood-inundation map that was developed for this study. The gage height during the field survey ranged from $24.07-24.24 \mathrm{ft}$. The primary purpose of the field survey was to spot check the extent of the flooding at various points along public roads throughout the study reach. An overview map of the inundation verification locations is shown in figure 1-5. Overall, there was good agreement between the 24-ft flood-inundation map and the flood extent on July 20, 2015. Documentation comparing the $24-\mathrm{ft}$ flood-inundation map with photographs of water over roads throughout the study reach are shown in figures 1-6 through 1-15. Figure 1-6 shows the water encroaching Spout Springs Road. Figure 1-7 shows the water over Spout Springs Road. Figure 1-8 shows the water over 2nd Street. Figure 1-9 shows the water over Weisbach Road (County Road 255). Figure 1-10 shows the water over 8th Street. Figure 1-11 shows the water over Main Street (County Road 91). Figure 1-12 shows the water over East River Road. Figure 1-13 shows the water over West River Road (County Road 17). Figure 1-14 shows the water over West River Road (County Road 225). Figure 1-15 shows the water over an unnamed gravel road through a field at the end of Elm Street.

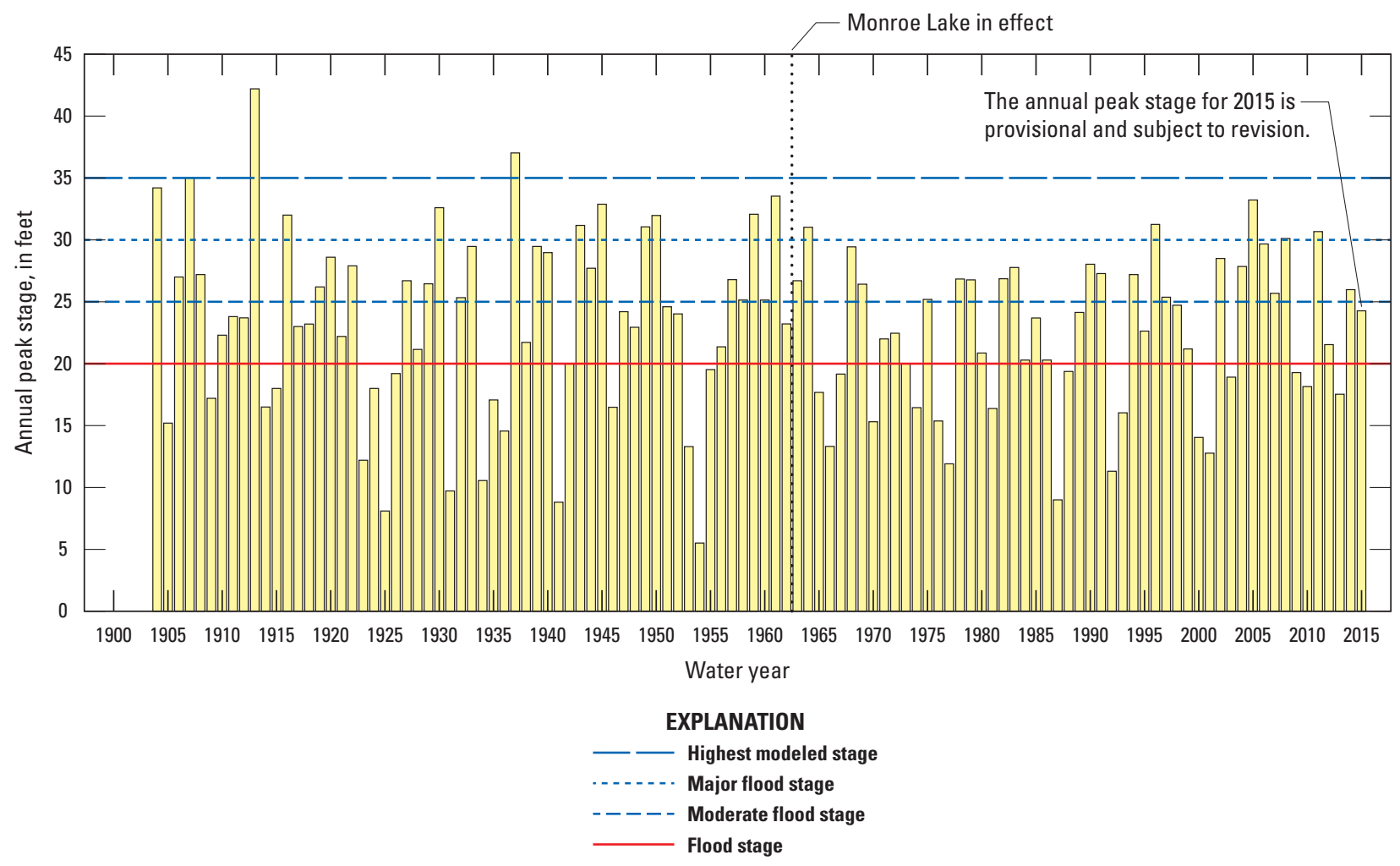

Figure 1-1. Peak stage at U.S. Geological Survey streamgage 03373500 for water years 1904-2015. 


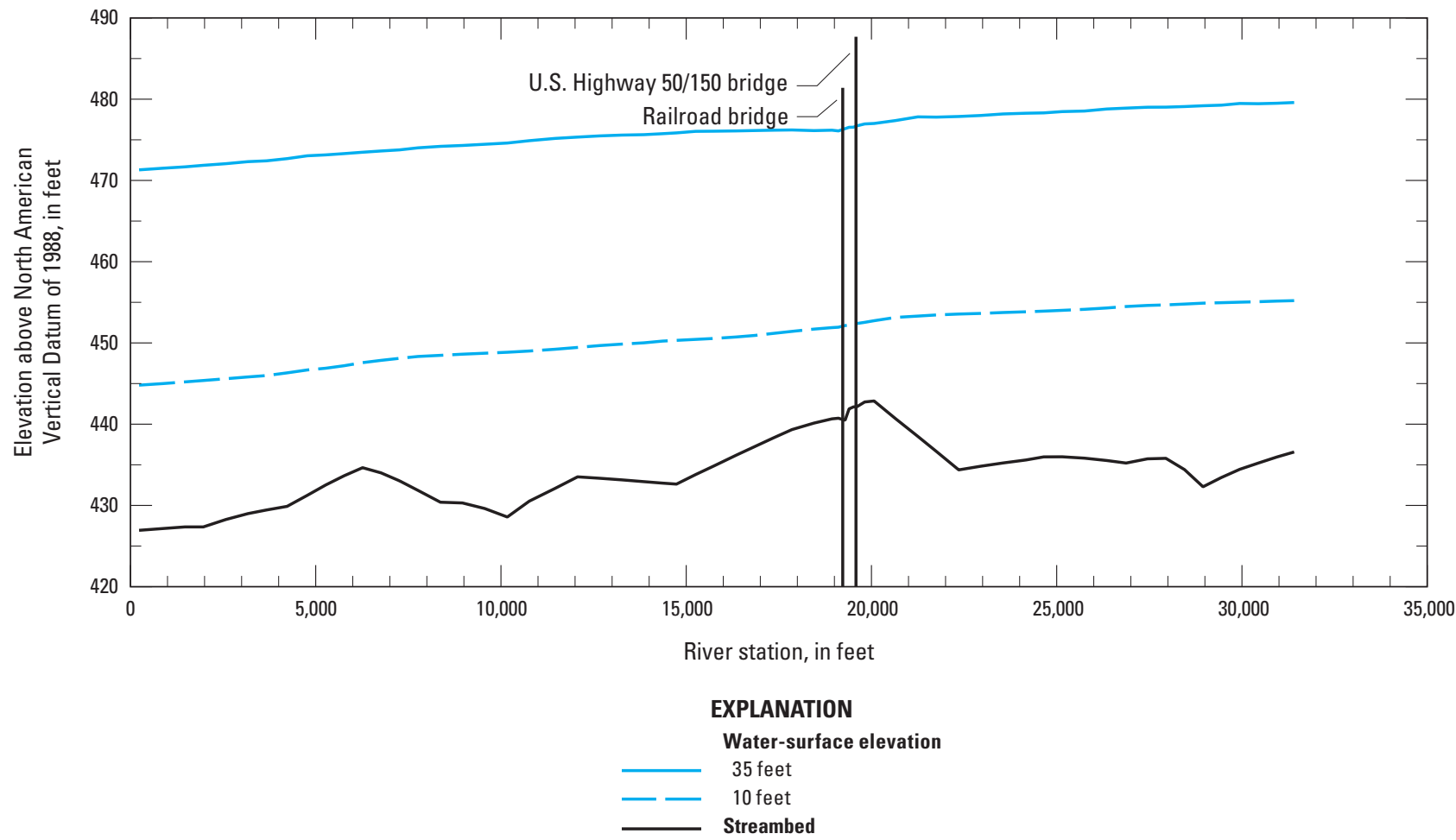

Figure 1-2. Water-surface profiles for the 5.9-mi study reach of the East Fork White River at Shoals, Indiana, corresponding to a discharge at a stage of $10 \mathrm{ft}$ and $35 \mathrm{ft}$. 


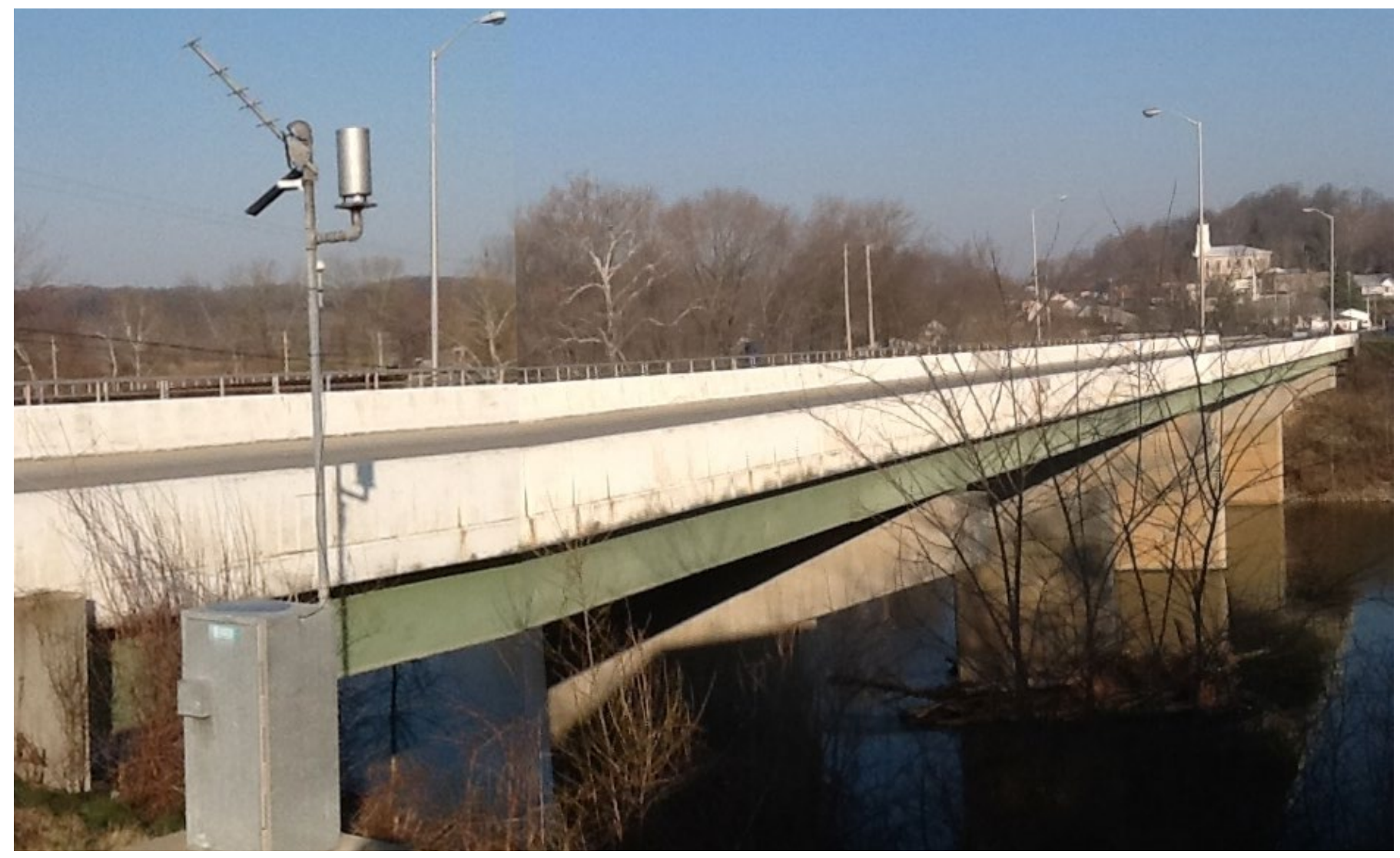

Figure 1-3. Upstream side of the U.S. Highway $50 / 150$ bridge on April 5, 2013. Photos by Chad Menke, U.S. Geological Survey.

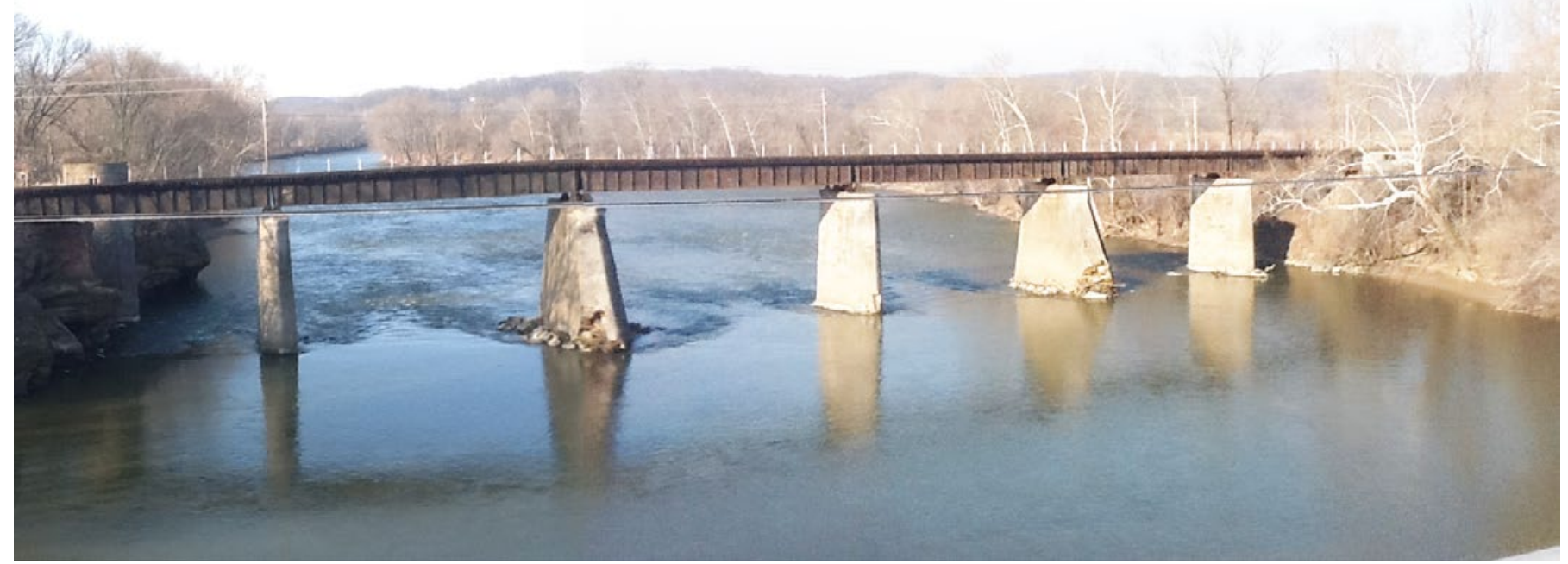

Figure 1-4. Upstream side of the railroad bridge on April 5, 2013. Photos by Chad Menke, U.S. Geological Survey. 


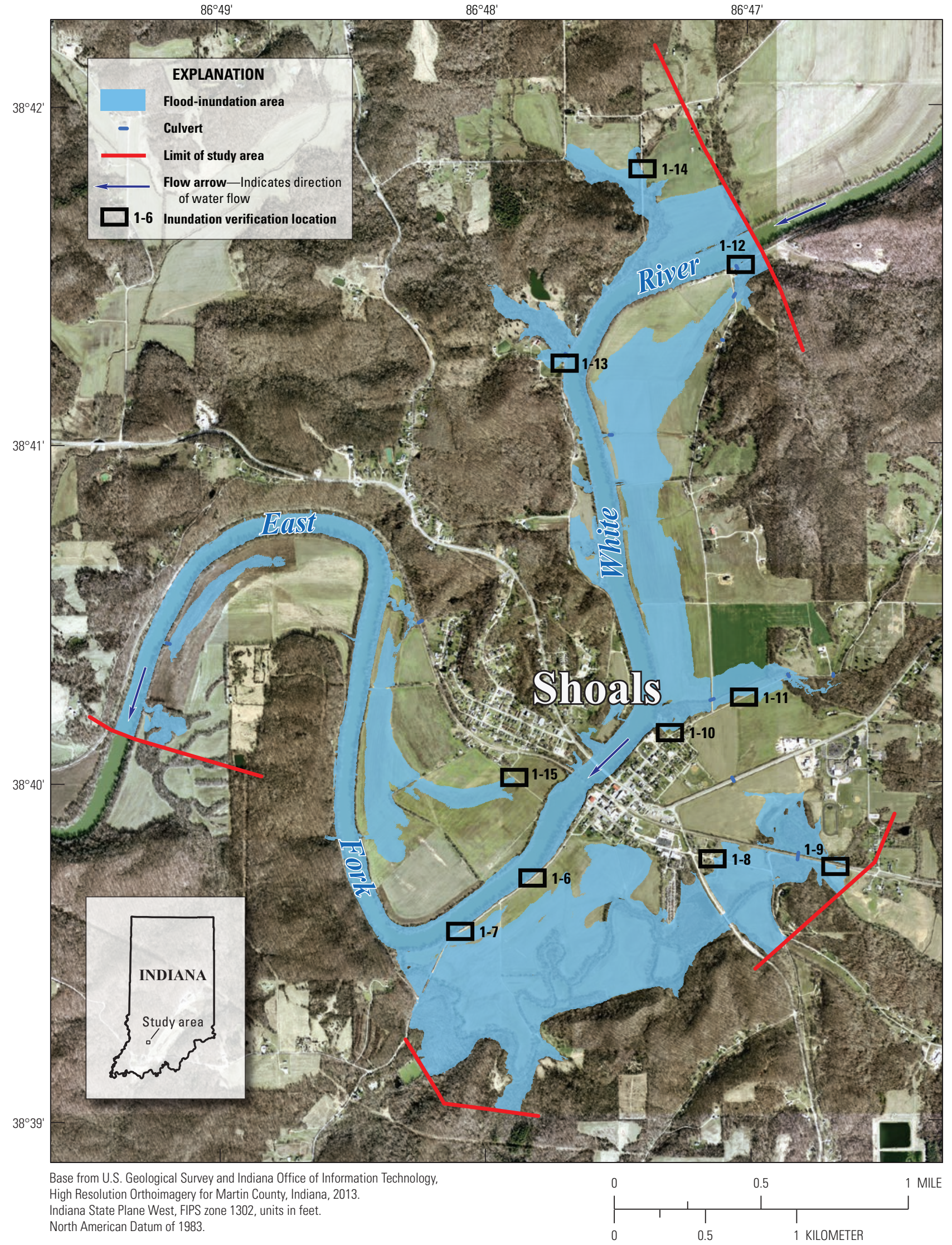

Figure 1-5. Overview map of inundation verification locations on July 20, 2015, along with the 24-ft flood-inundation map. 


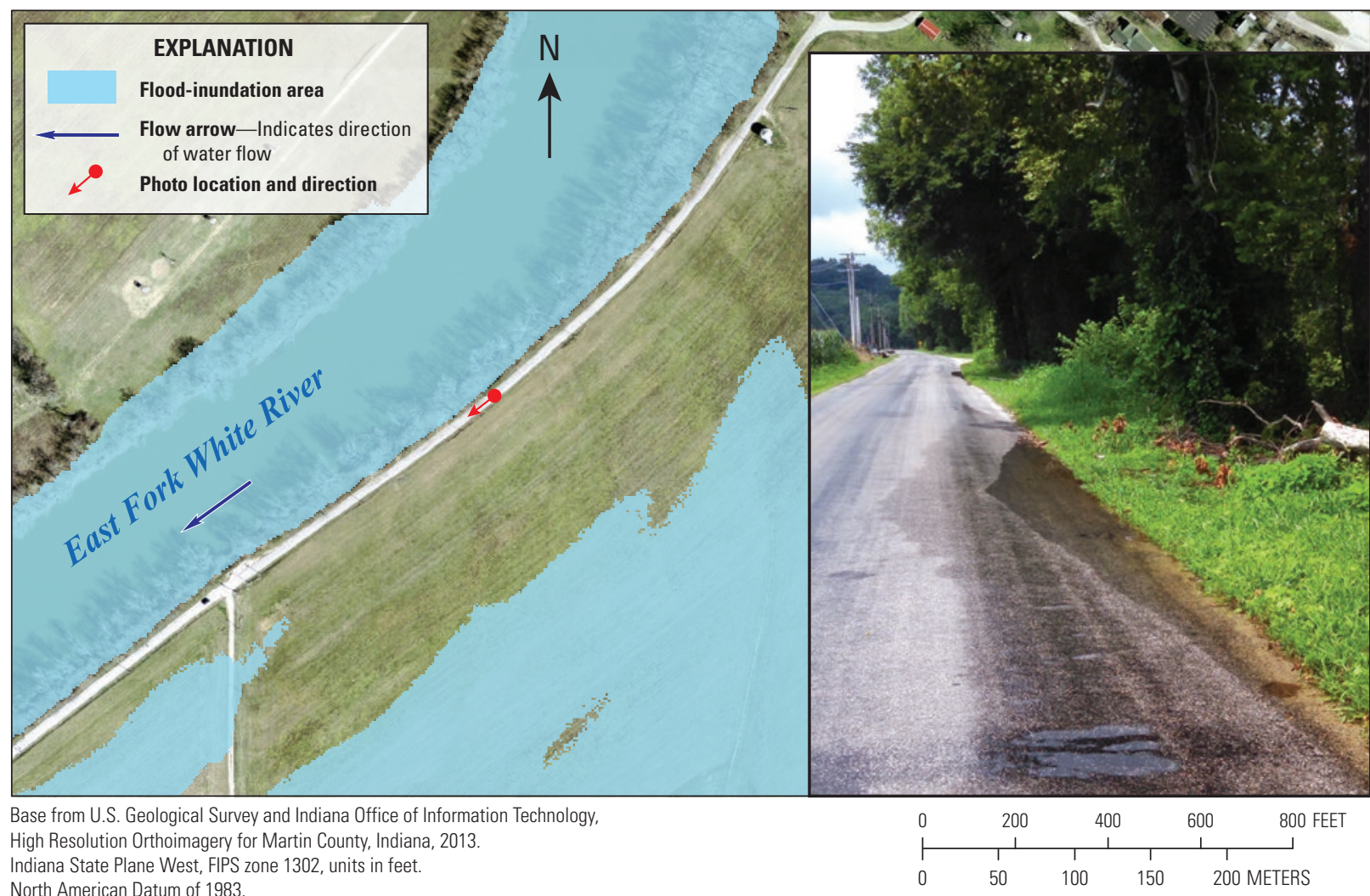

Figure 1-6. 24-ft flood-inundation map and photo of water encroaching Spout Springs Road on July 20, 2015 (gage height at time of photo was $24.13 \mathrm{ft}$ ). Photo by Justin A. Boldt, U.S. Geological Survey.

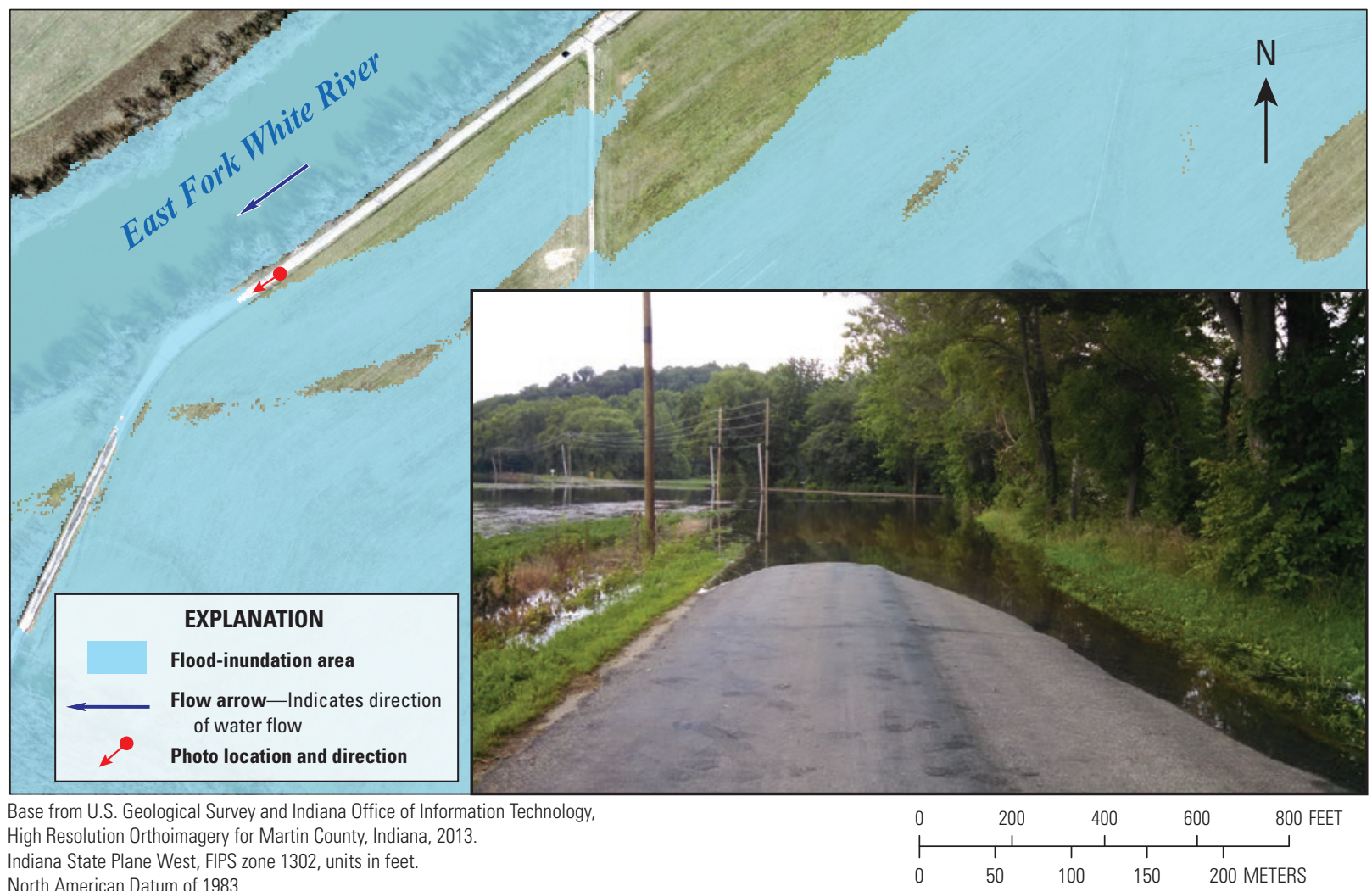

Figure 1-7. 24-ft flood-inundation map and photo of water over Spout Springs Road on July 20, 2015 (gage height at time of photo was $24.12 \mathrm{ft}$ ). Photo by Justin A. Boldt, U.S. Geological Survey. 


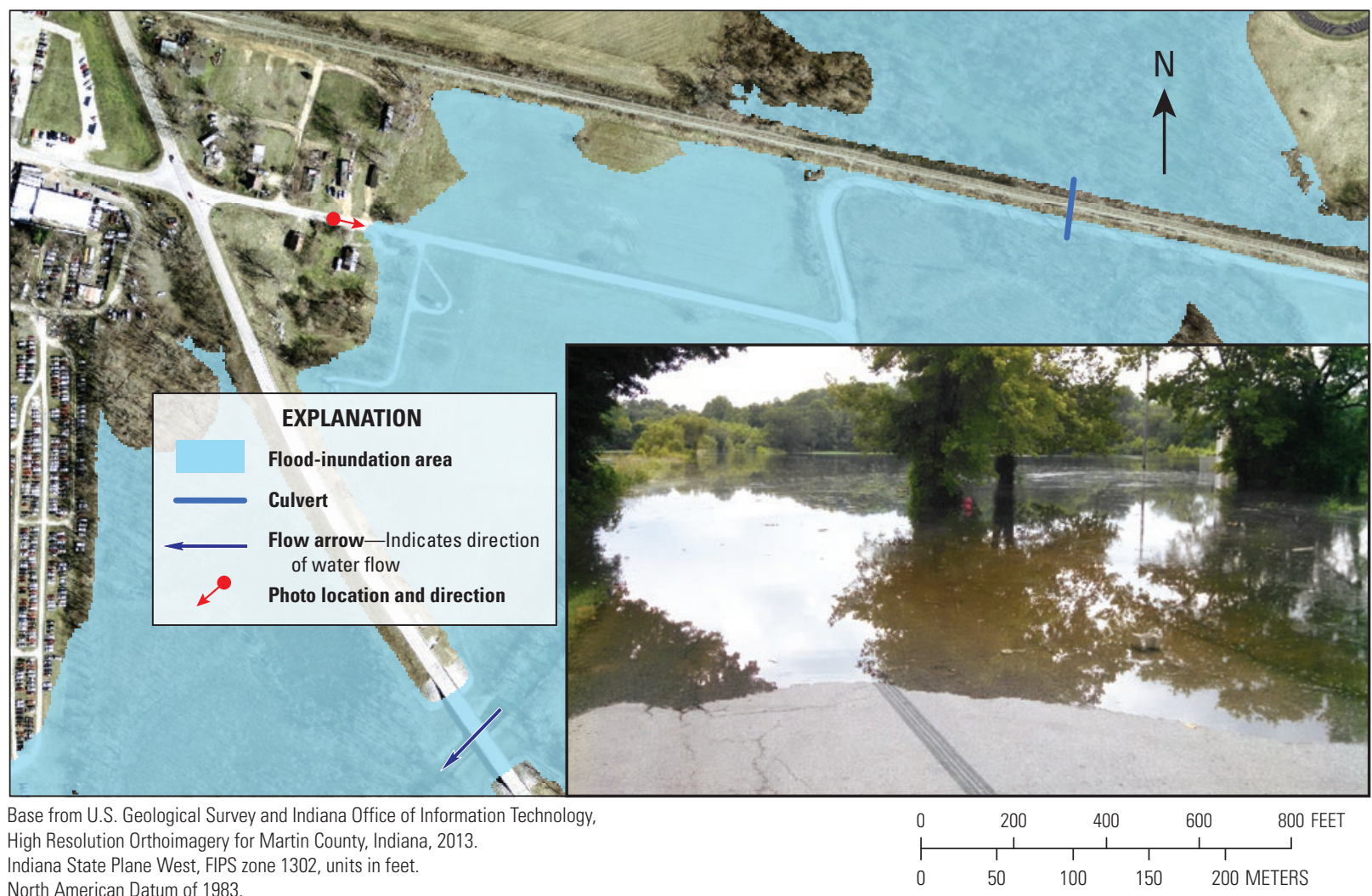

Figure 1-8. 24-ft flood-inundation map and photo of water over 2nd Street on July 20, 2015 (gage height at time of photo was $24.11 \mathrm{ft}$ ). Photo by Justin A. Boldt, U.S. Geological Survey.

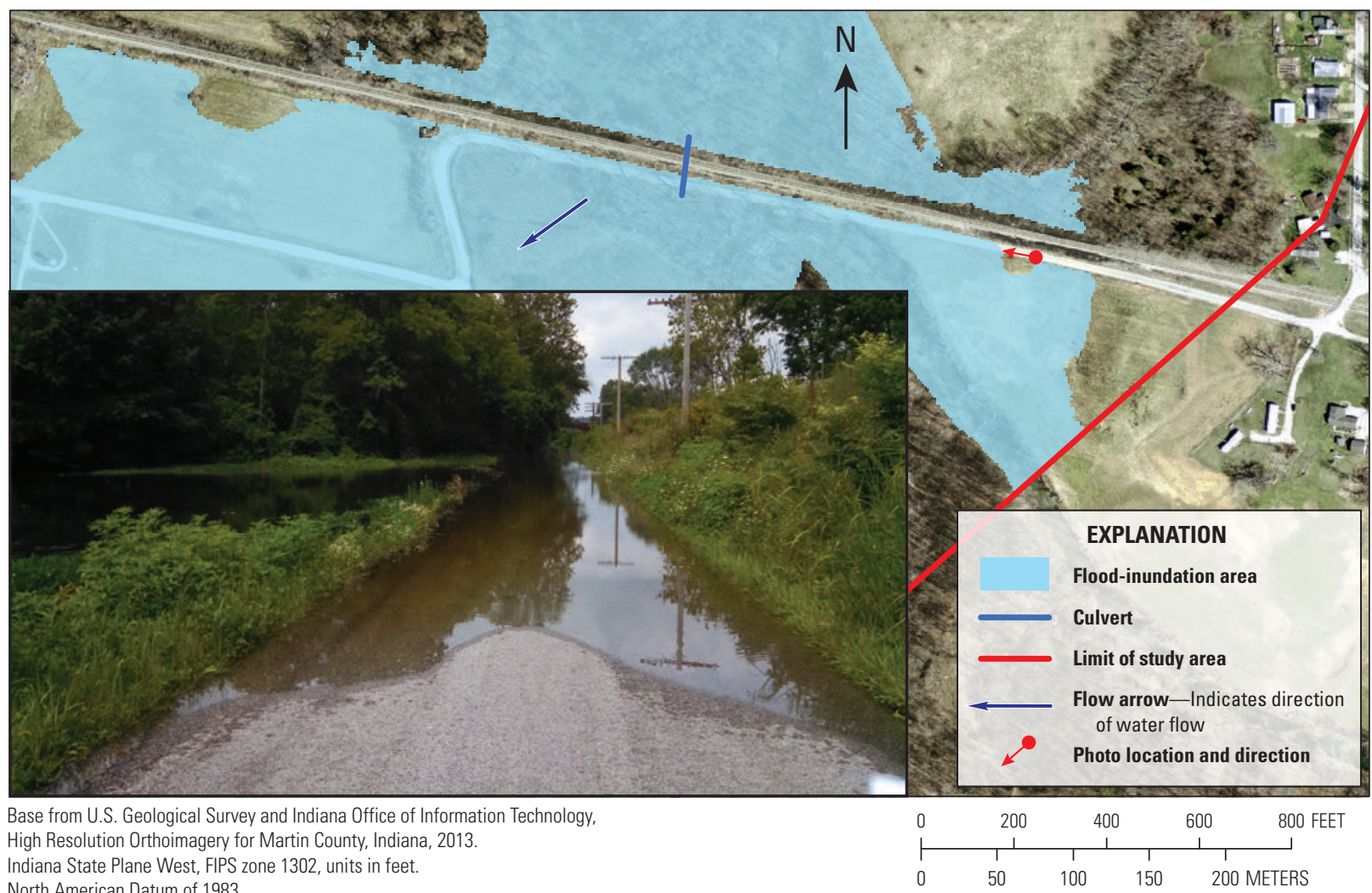

Figure 1-9. 24-ft flood-inundation map and photo of water over Weisbach Road (County Road 255) on July 20, 2015 (gage height at time of photo was $24.07 \mathrm{ft}$ ). Photo by Justin A. Boldt, U.S. Geological Survey. 


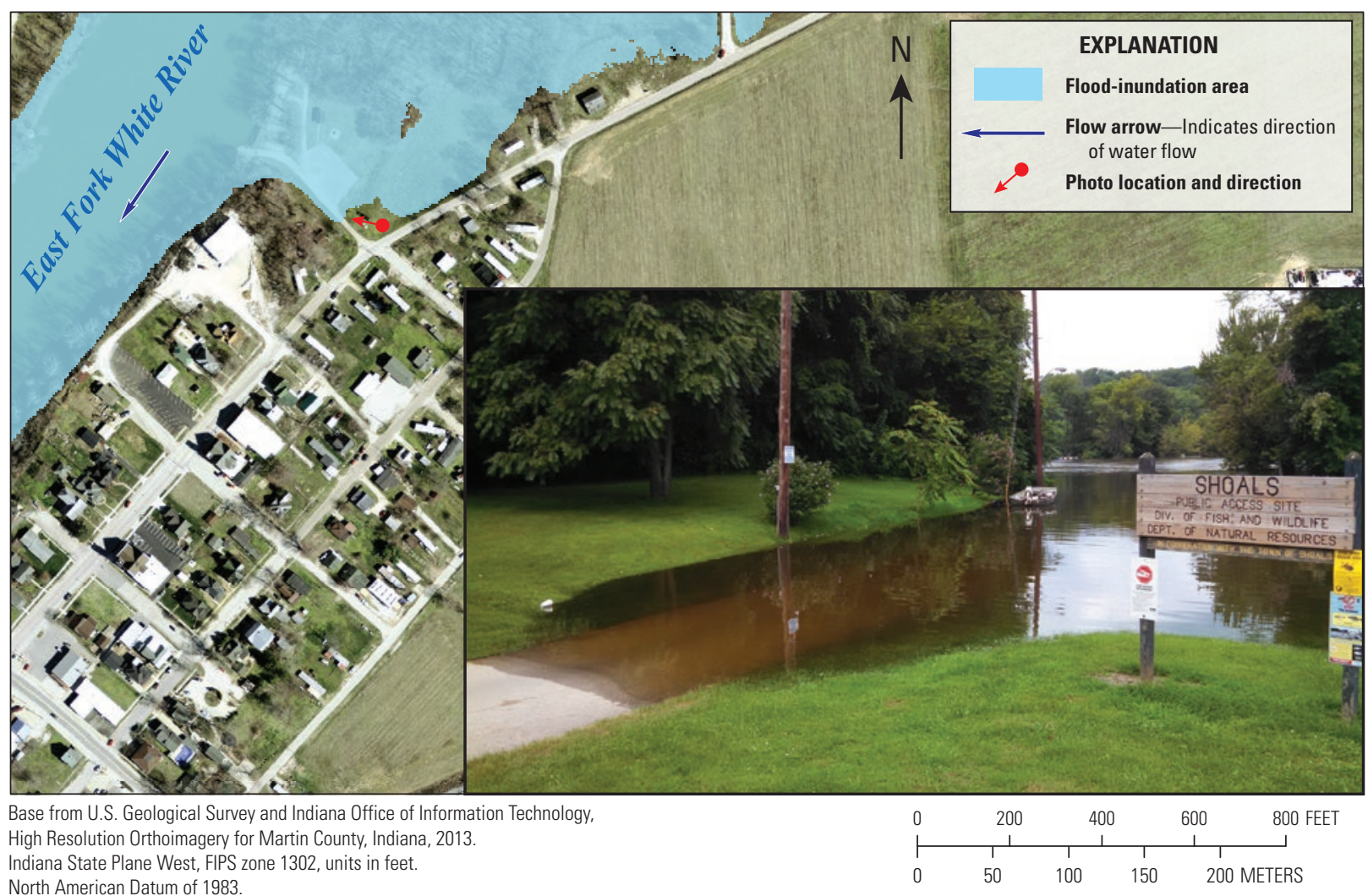

Figure 1-10. 24-ft flood-inundation map and photo of water over 8th Street on July 20, 2015 (gage height at time of photo was $24.18 \mathrm{ft})$. Photo by Justin A. Boldt, U.S. Geological Survey.

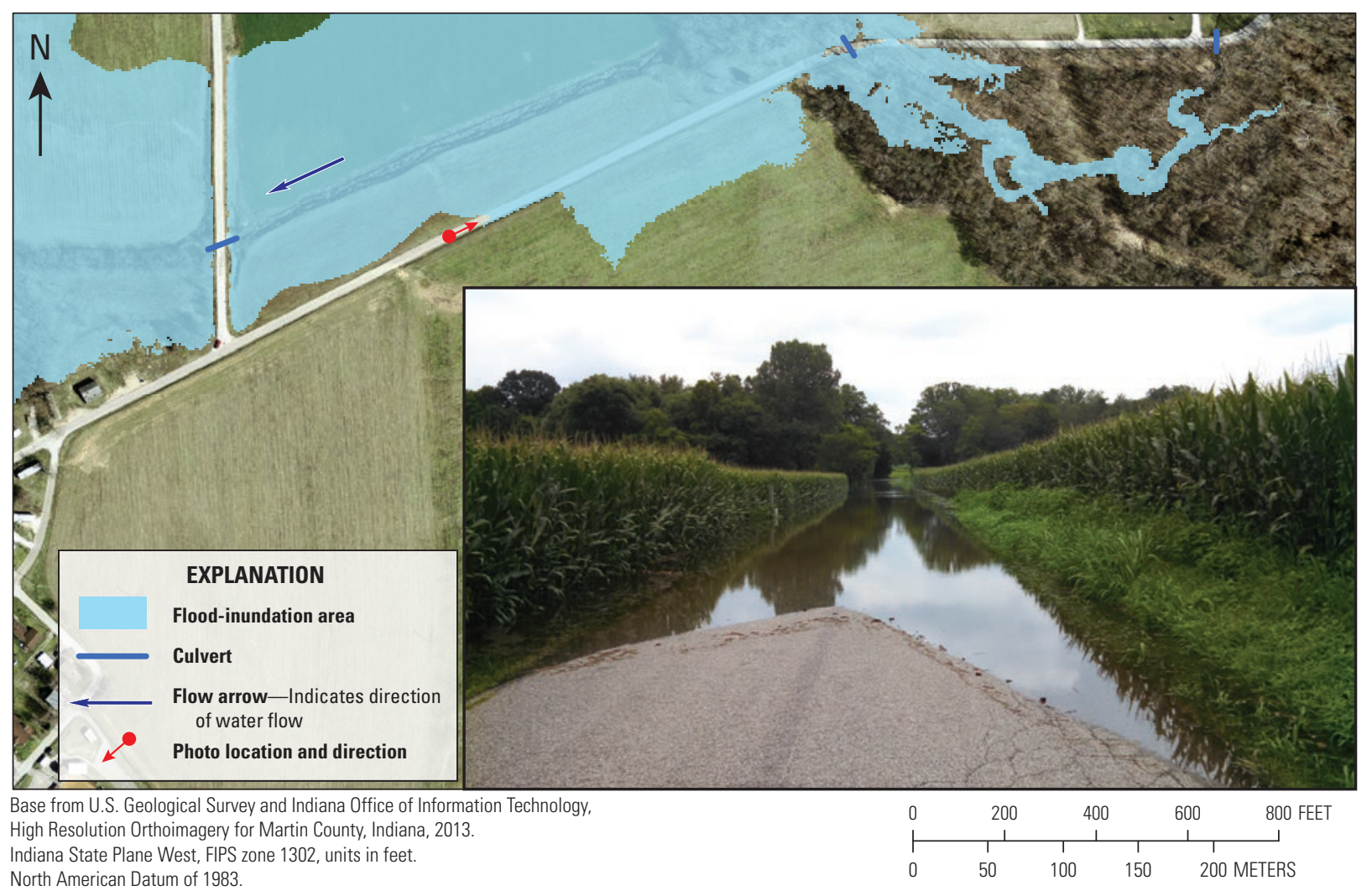

Figure 1-11. 24-ft flood-inundation map and photo of water over Main Street (County Road 91) on July 20, 2015 (gage height at time of photo was $24.17 \mathrm{ft}$ ). Photo by Justin A. Boldt, U.S. Geological Survey. 


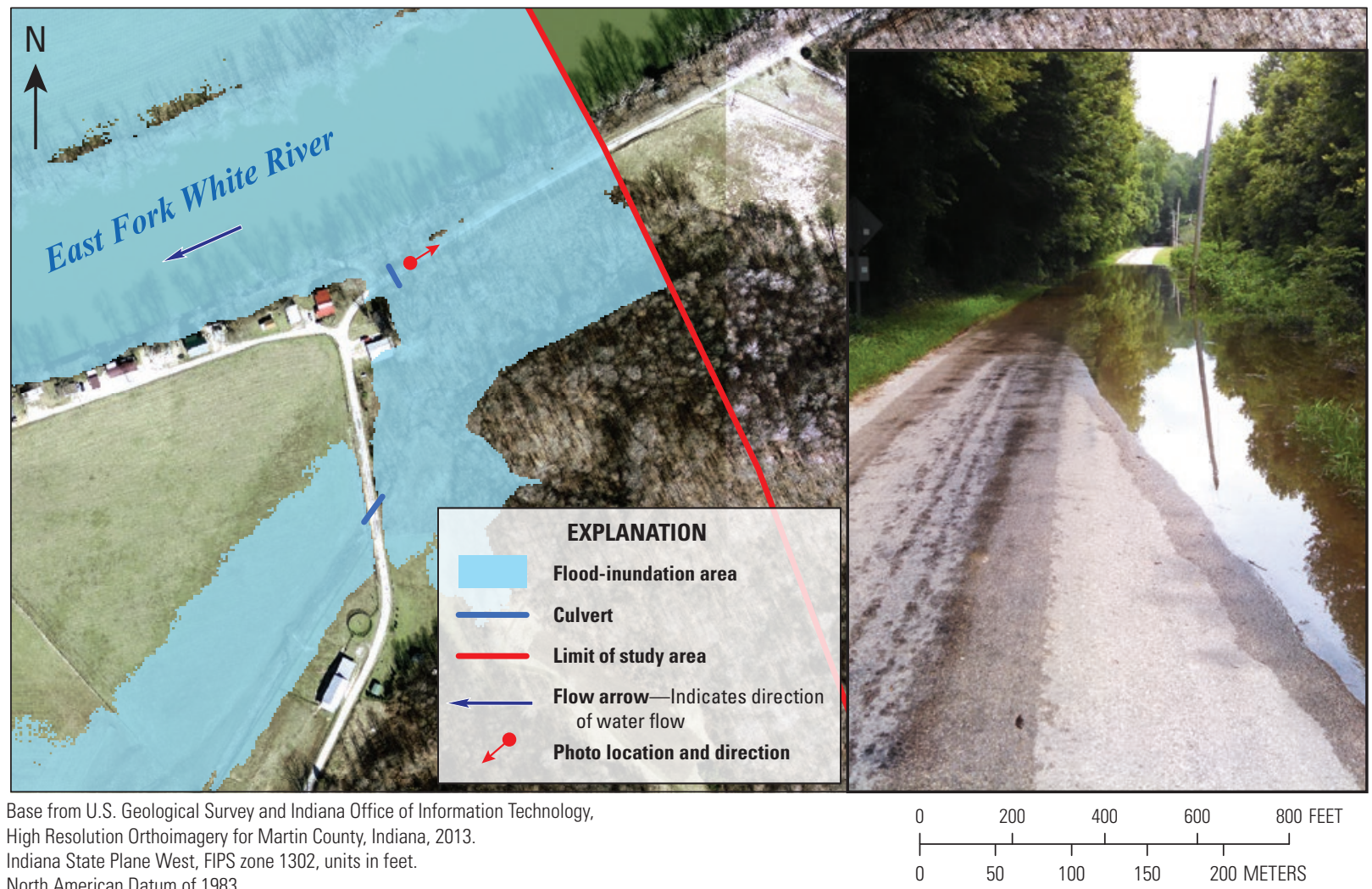

Figure 1-12. 24-ft flood-inundation map and photo of water over East River Road on July 20, 2015 (gage height at time of photo was $24.17 \mathrm{ft}$ ). Photo by Justin A. Boldt, U.S. Geological Survey.

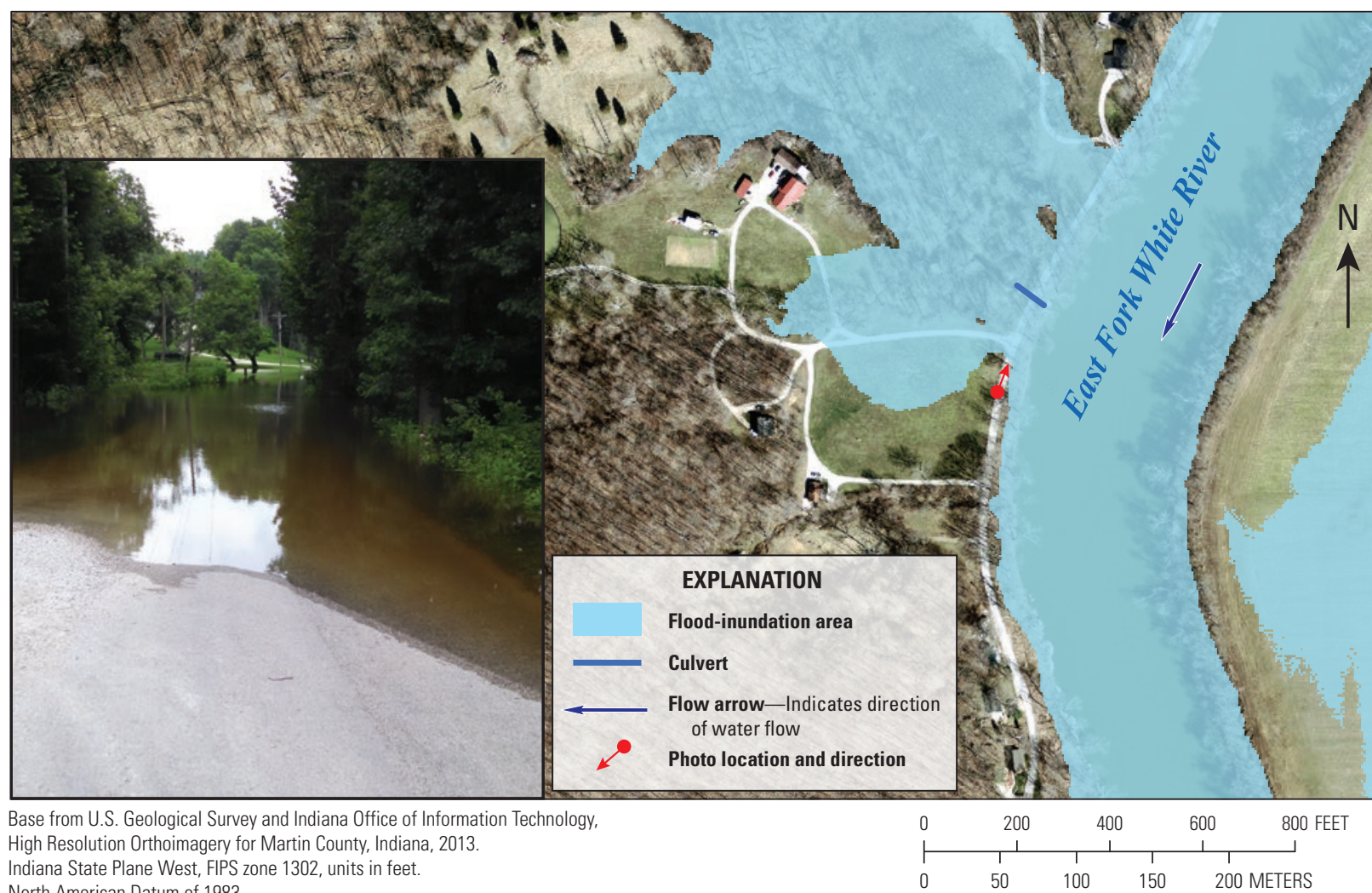

North American Datum of 1983.

Figure 1-13. 24-ft flood-inundation map and photo of water over West River Road (County Road 17) on July 20, 2015 (gage height at time of photo was $24.21 \mathrm{ft})$. Photo by Justin A. Boldt, U.S. Geological Survey. 


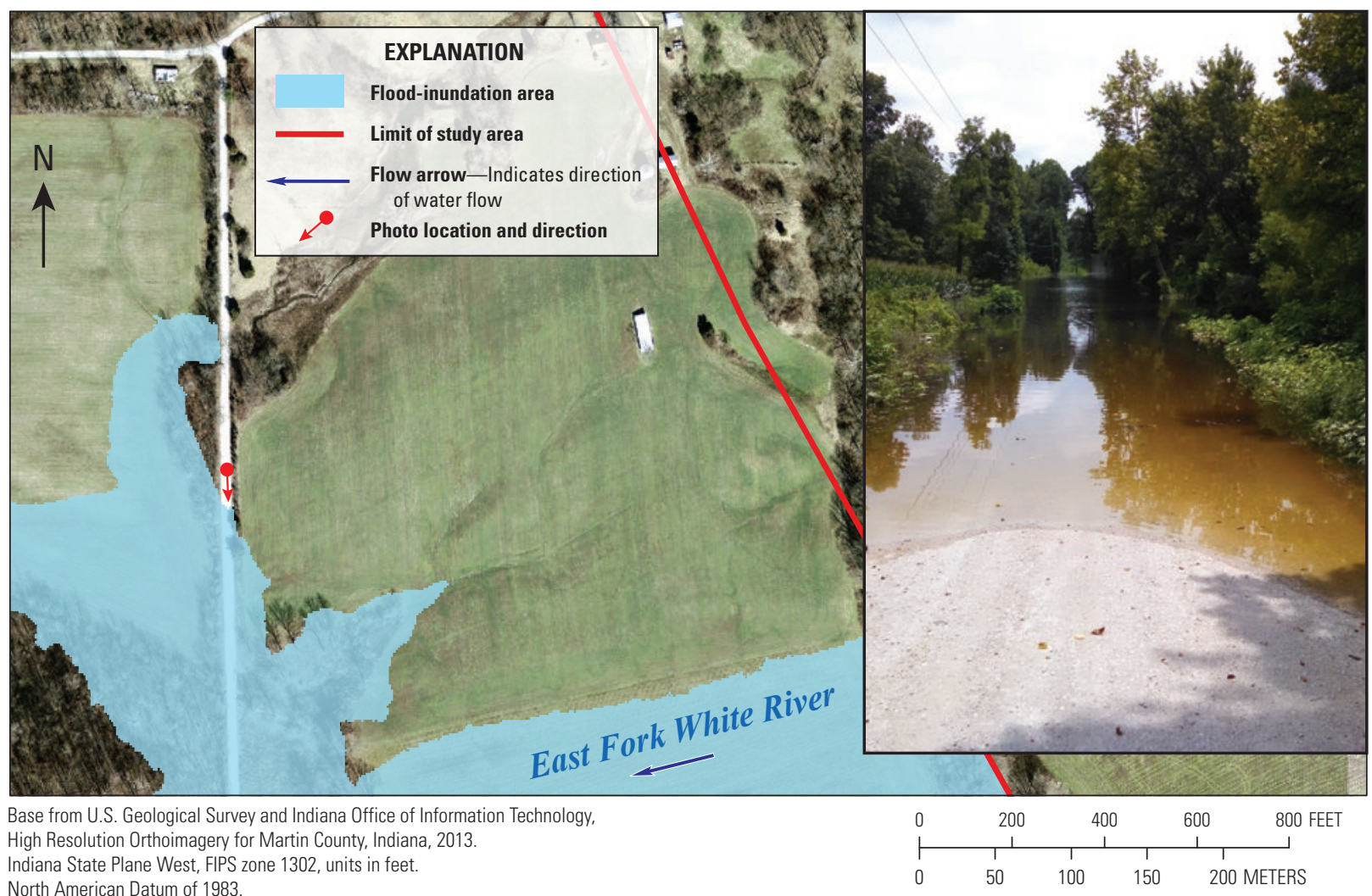

North American Datum of 1983.

Figure 1-14. 24-ft flood-inundation map and photo of water over West River Road (County Road 225) on July 20, 2015 (gage height at time of photo was $24.18 \mathrm{ft}$ ). Photo by Justin A. Boldt, U.S. Geological Survey.

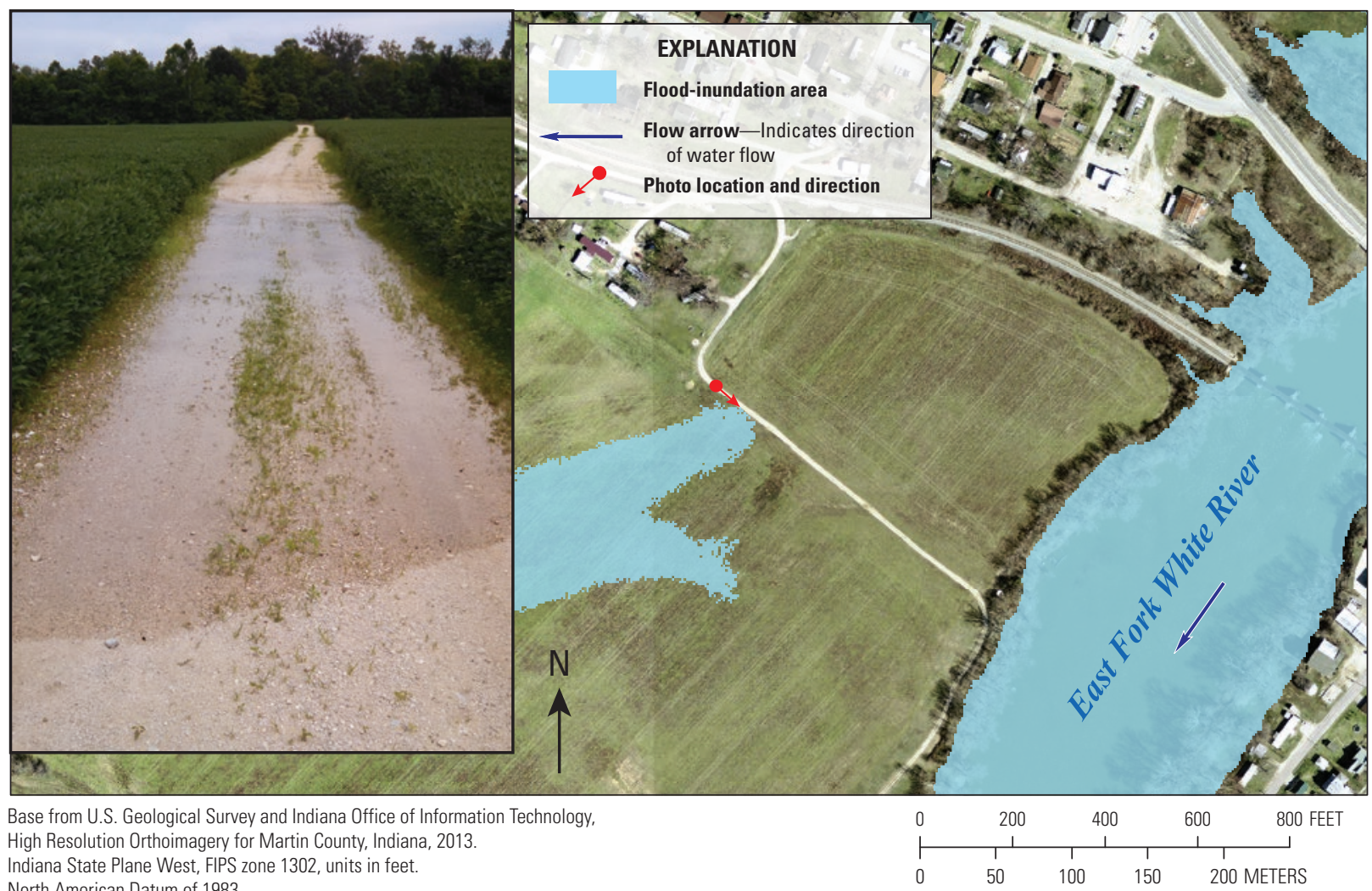

North American Datum of 1983.

Figure 1-15. 24-ft flood-inundation map and photo of water over an unnamed gravel road through a field at the end of Elm Street on July 20, 2015 (gage height at time of photo was $24.22 \mathrm{ft}$ ). Photo by Justin A. Boldt, U.S. Geological Survey. 
For more information concerning the research in this report, contact: Director, Indiana-Kentucky Water Science Center

U.S. Geological Survey

5957 Lakeside Blvd

Indianapolis, IN 46278

http://in.water.usgs.gov/ 


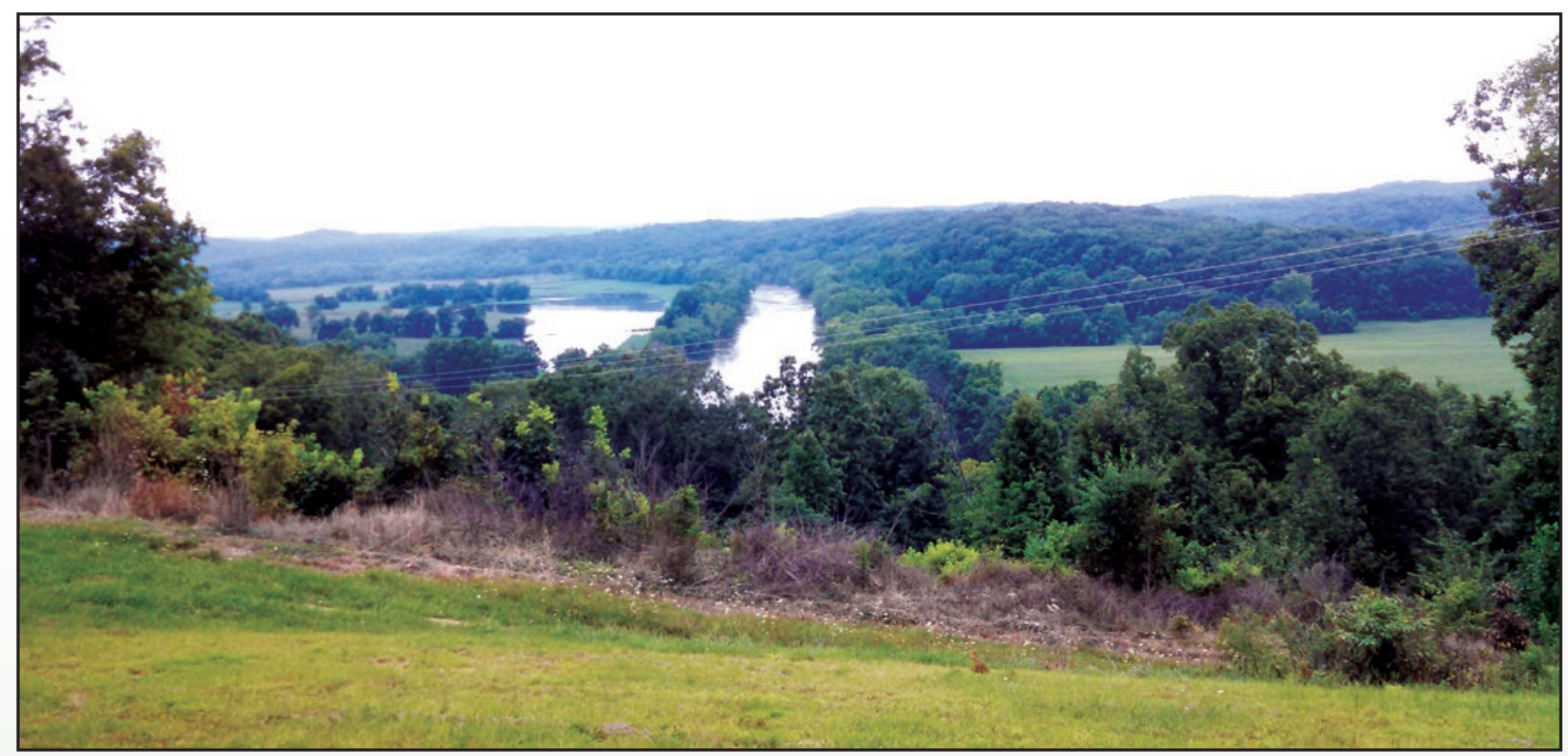

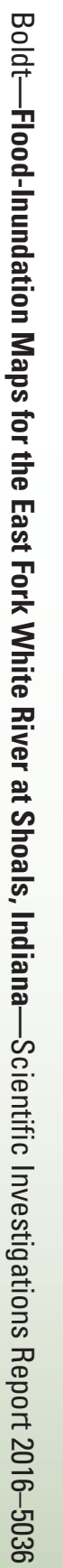

